\title{
An elusive experiential tense construction in Latvian
}

\author{
Anna Daugavet \\ Vinius University \& St Petersburg University
}

Axel Holvoet

Vilnius University

The article is a contribution to the study of experiential and indefinite past-tense forms. It offers an analysis of the Latvian past-tense construction tikt + PPA, which is now a feature of the Latvian standard language though it was originally restricted to Eastern Latvia (probably mainly the High Latvian dialects). It can be characterised as an experiential but has a wider scope than the prototypical experiential, which refers to event types in the past without precise location in time. The Latvian construction with tikt can also refer to events that are more precisely anchored in time and then develops into a non-resultative and nonnarrative past-tense form reminiscent of the factual imperfective in Russian. The question is also raised whether differences can be found between the use of the construction tikt + PPA in texts reflecting its distribution in the regional dialects where it used to be indigenous and in the modern standard language.

Keywords: Latvian, indefinite past tense, experiential, event type, event token, factual imperfective

\section{Introduction ${ }^{1}$}

This article deals with a Latvian construction (described in Latvian grammars as a tense form) used to refer to events in the past, consisting of the verb tikt 'get, become' and a past active participle. It is illustrated here with example (1):

\footnotetext{
${ }^{1}$ We wish to thank two reviewers for their insightful and constructive criticisms, Anna Stafecka for answering our questions in the domain of Latvian dialectology, and Peter Arkadiev, Nicole Nau and Rolandas Mikulskas for their useful comments on our draft version. For all remaining shortcomings of the article we are solely responsible. This research has received funding from the European Social Fund (project No. 09.3.3-LMT-K-712-01-0071) under grant agreement with the Research Council of Lithuania (LMTLT).
} 


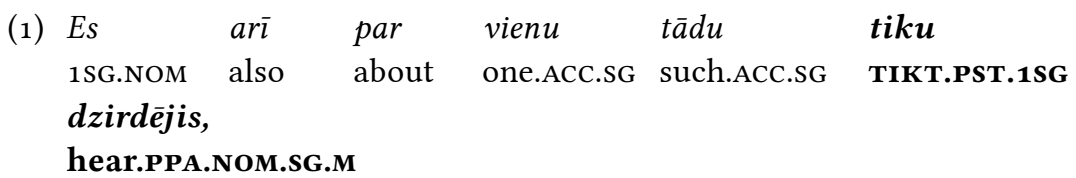
[kas 9o-tajos iesaistījās bandā tikai tāpat, joka pēc.]

'I have also heard about one person [who, in the 1990s, became a gang member just like that, for a joke.]'2

The construction tiku dzirdejis is reminiscent of, and (at least in this case) could be replaced with, the perfect esmu dzirdējis. The Latvian perfect consists of the auxiliary büt 'be' and the past active participle, and is part of a system of absolute and relative tenses shown in Table 1:

Table 1. The Latvian tense system

\begin{tabular}{|c|c|c|}
\hline & Simple & Perfect \\
\hline Present & $d z i r d u$ 'I hear' & $\begin{array}{l}\text { esmu dzirdējis (M), dzirdējusi (F) } \\
\text { 'I have heard' }\end{array}$ \\
\hline Past & dzirdēju 'I heard' & $\begin{array}{l}\text { biju dzirdējis (M), dzirdējusi (F) } \\
\text { 'I had heard' }\end{array}$ \\
\hline Future & dzirdēšu 'I will hear' & $\begin{array}{l}\text { būšsu dzirdējis (м), dzirdējusi (F) } \\
\text { 'I will have heard' }\end{array}$ \\
\hline
\end{tabular}

The construction tiku dzirdējis/dzirdējusi, on the other hand, does not enter a regular form correlation like the 'be'-perfect does. Though tiku $d z i r d e j i s$ would, in (1), correspond to a present perfect, tiku is actually a past tense, and there is no corresponding construction with a present tense

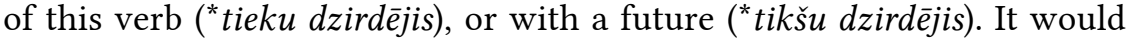
be hard, therefore, to find a fitting slot for it in the conjugation tables for Latvian verbs, but it is nevertheless mentioned in Latvian grammars as a variety of the past tense or the perfect (for details see below). As we will show below, the construction under discussion has certain functions that coincide with those of the experiential perfect, but it also has functions that could alternatively be expressed by the pluperfect, and such as could alternatively be expressed by the simple past. In each of these types of use, it could actually be replaced with these respective tense forms, and

\footnotetext{
${ }^{2}$ https://nra.lv/viedokli/viktors-avotins/229763-valsts-pilsonis-nav-valsts-ipasums.htm/komentari
} 
its use is never obligatory. It usually asserts or negates the occurrence of an event or a series of events at an indefinite moment in the past, and in this sense it has certain features of what Dahl $(1985,139-144)^{3}$ calls 'experiential', a tense form referring mainly to event types in the past. However, the construction with tikt is not a prototypical experiential in the sense that it can also refer, in specific cases, to event tokens. In this article we will endeavour to get a better understanding of the functioning of our construction.

The structure of the article is as follows. First, we will briefly characterise the empirical basis for our research, including the corpora available for Latvian, and the sociolinguistic history of Latvian, as this is indispensible for a correct understanding of the occurrence of our construction. Next, in order to provide a context for the use of the verb tikt as an auxiliary, we will give an overview of verbal constructions headed by this verb. We will then concentrate on the construction based on the preterite $t i k u$ and the active past participle, which, unlike other constructions with tikt, is not indigenous in all regional dialects of Latvian. We will analyse its use on the basis of texts written by representatives of the regional dialects that have the construction, and attempt to formulate the principles of its use. Next, we will examine the situation in contemporary written standard Latvian, and we will pose the question whether the character of the construction has changed in the process of its becoming a feature of the standard language.

\section{Corpora and other sources}

We have used several Latvian language corpora, almost all of them found at korpuss.lv. The Balanced Corpus of Modern Latvian (in its older version called miljons-2.o.) and the Corpus of Saeima (Latvian Parliament) Proceedings represent the modern standard language, and the corpus of texts by the Latvian classic Jānis Rainis reflects the usage of the second half of the 19th century. Another source on 19th century Latvian which we have used is the literary production of Jānis Jaunsudrabiṇš, especially his novels Baltā grāmata ('The White Book') and Zaḷā grāmata ('The Green Book').

\footnotetext{
3 The term seems, however, to have originated in grammatical descriptions of certain individual languages, such as Mandarin (Östen Dahl, p.c.).
} 
The miljons-2.o corpus contains written texts, both fiction and nonfiction, from the last decade of the 2oth century. Miljons-2.o was used to extract all instances of the verb tikt in 2013-2014, when it had $3.5 \mathrm{mln}$ words. The data it contained have now been integrated into a new version of the Balanced Corpus of Modern Latvian (LVK2013, 4.5 mln words). The Saeima (Parliament) corpus ( $17.5 \mathrm{mln}$ words) is, in essence, a transcript of sessions of the Latvian Parliament from the last decade of the zoth century up to 2018, and therefore reflects elements of (admittedly not always quite spontaneous) spoken language. The Rainis corpus (further referred to as Rainis) contains $1.5 \mathrm{mln}$ words and can be searched at http://nosketch. korpuss.lv/run.cgi/first?corpname=rainis .

\section{The sociolinguistic history of standard Latvian}

For more background information on Latvian the reader can be referred to Balode and Holvoet (2001). For the purposes of our article it is important to note that standard Latvian as we now know it is of relatively recent origin. Latvian is attested from the 16 th century, but until the 19th century Latvian texts were written mainly by German pastors for the use of the Lutheran (less frequently Roman Catholic) churches in Latvia. The national revival in the 19th century led to the rise of a Latvian literary idiom cultivated by ethnically Latvian authors. The establishment of the Republic of Latvia in 1918 ushered in the introduction of Latvian in all spheres of public life, and Standard Latvian began to oust the popular dialects. The dialectal base for Standard Latvian (often referred to as the 'central dialect' of Low Latvian) had been established since the 17 th century, but Latvian writers from the mid-19th century up to World War II were also speakers of their regional dialects, and some characteristics of these dialects are reflected in their language. The final consolidation of Standard Latvian took place after World War II.

The construction to be discussed in this article was originally indigenous only to part of the regional dialects of Latvian. This does, however, not apply to all grammatical or semi-grammatical constructions in which the verb tikt occurs, but just to this one. In order to provide a broader context for the discussion of our construction, we will start with an overview of 
the different functions of tikt in Latvian grammar, after which we will focus on the construction $t i k u+$ past active participle.

\section{The place of the verb tikt in Latvian grammar}

This section discusses the various uses of tikt on the basis of Daugavet (2015), where various uses of this verb are analysed as they are found in a subcorpus of the older version of the Balanced Corpus of Modern Latvian called miljons-2.o. The subcorpus is also the source of all examples in the current section, although at one point we will refer to the Rainis corpus, which provides a comparison with an earlier stage of the Latvian literary language. This section also discusses dialectal variation.

Latvian tikt, which replaced (through a change in ablaut pattern, cf. Endzelin 1923, 60) an original Proto-Latvian form * tekti, is the exact etymological counterpart of Lithuanian tekti, which (by itself or combined with prefixes) has the meanings 'get to some place, find oneself somewhere, fall to somebody's share, happen, be necessary'. This Baltic lexeme has no reliable etymology; the Lexicon of Indo-European Verbs (Rix et al., eds. 2001, 619) derives it from an Indo-European stem *tek- 'hold out a hand, reach out', cf. also Smoczyński 2018, 1465), but it seems reasonable to assume that the intransitive spatial meaning 'get to some place' was the original one for Baltic, and that it underlies the possessive as well as the implicative and modal meanings.

In modern Latvian, the meaning of tikt is similar to that of English get in its intransitive uses. The general idea is a subject's translocation or change of state. This meaning becomes more specific in combination with certain case forms of nouns, as well as with adverbs, adjectives, and participles. In this last case, tikt develops into an auxiliary. The constructions reflecting the different stages of this development can be grouped into two major classes. The first class is translocational or involves a clearly discernible translocational metaphor, and apart from adverbs it also comprises locative case forms of nouns as well as prepositional phrases. The second class can be called 'copular' and it contains combinations of tikt with adjectives and adjective-like participles, predicative nouns and prepositional phrases with the predication marker par. An overview is given in Table 2 . 
Table 2. The functions of tikt in Latvian grammar

\begin{tabular}{|c|c|c|}
\hline class & meaning & construction \\
\hline translocational & $\begin{array}{l}\text { strictly } \\
\text { translocational } \\
\text { translocation > } \\
\text { inceptive possession } \\
\text { translocation > } \\
\text { implicative/modal }\end{array}$ & $\begin{array}{l}t i k t+\mathrm{LOC} / \mathrm{PP} / \mathrm{ADV} \\
t i k t+\mathrm{DAT} \\
t i k t+(\mathrm{LOC} / \mathrm{PP}) \mathrm{INF}\end{array}$ \\
\hline copular & $\begin{array}{l}\text { change of state > } \\
\text { ingressive copula } \\
\text { ingressive copula > } \\
\text { dynamic passive } \\
\text { ingressive copula > } \\
\text { perfect-like construction }\end{array}$ & $\begin{array}{l}t i k t+\mathrm{ADJ} / \mathrm{NOM} / p a r+\mathrm{ACC} \\
t i k t+\mathrm{PPP} \\
t i k t+\mathrm{PPA}\end{array}$ \\
\hline
\end{tabular}

\subsection{Translocational constructions}

The verb tikt denotes translocation when combined with directional locatives, adverbs, and various prepositional phrases (with the important exception of those with the preposition par, which will be discussed separately below).

(2) Dušā toreiz tikām reizi nedēḷā. shower.LOc.sg then TIKT.PST.1PL time.ACC.SG week.LOC.sG 'We only got to the shower one time a week in those days.'

(3) [Centos uzmanities,] tomèr sula tika uz rokas $<\ldots>$ but juice.NOM.sG TIKT.PsT.3 on hand.gen.sg

'[I tried to be careful] but the juice got on my hand $<\ldots$ '

(4) [Dažkārt pagāja dienas,]

$\begin{array}{llll}\text { lìdz } & \text { Florence } & \text { tika } & \text { atpakal, } \\ \text { before } & \text { Florence.NOM.SG } & \text { TIKT.PST.3 } & \text { back } \\ \text { nogurusi } & \text { un } & \text { nikna. } & \\ \text { tired.NOM.SG.F } & \text { and } & \text { angry.NOM.SG.F }\end{array}$

'[Sometimes it was days] before Florence got back, tired and angry.' 
The place that a subject moves to may be omitted if it is obvious to both speaker and addressee, as in the following example about passing entry examinations:

(5) [Vakar paziņoja eksāmenu rezultātus.]

$\begin{array}{lll}\text { Katrina } & \text { ir } & \text { tikusi. } \\ \text { PN.NOM.SG } & \text { be.PRS.3 } & \text { TIKT.PPA.NOM.SG.F }\end{array}$

'[They published the examination results yesterday.]

Katrīna has got in [sc. into university.']

Directional locatives, adverbs and prepositional phrases are grouped together here not only because of their shared meaning of translocation. Very common with tikt are local adverbs, some of which originate as locative forms of nouns, such as iekšā 'inside', laukā 'outside', while others, such as pāri 'across', double as adverbs and adpositions (as they can assign case, like prepositions, they are termed 'relational adverbs' by Lagzdina 1998).

(6) $<\ldots>$

$\begin{array}{lllll}\text { tramvajā } & \text { gan } & \text { es } & \text { bez } & \text { palìdzības } \\ \text { tram.LOC.SG } & \text { PTC } & \text { 1SG.NOM } & \text { without } & \text { help.GEN.SG }\end{array}$

iekšā netieku.

inside NEG.TIKT.PRS.1SG

'<... but I cannot get onto the tram without help'

(7) $K \bar{a}$ viņi pāri robežai tiek?

how 3.NOM.PL.M across border.DAT.SG TIKT.3.PRS

'How do they get across the border?'

The same constructions can refer to a change of state:

(8) $<\ldots>$ [it kā cilvēki kā cilvēki, bet, $]$

kad tiek kopā,

when TIKT.PRS.3 together

[tad gluži kā zvēri pret to vienu.]

$'<\ldots>$ [they look like normal people but,] when they get together,

[then they are like beasts towards that lone one.]'

(9) $<\ldots>$ tieši šajā vietāalmss

exactly this.LOc.sG place.LOc.sG Sherlock.NOM.sG Holmes.NOM.SG

tika val̄ā no profesora Moriartija.

TIKT.PST.3 free from professor.gen.sg Moriarty.GEN.sG

$'<\ldots>$ it is exactly in this place that Sherlock Holmes got rid of / broke

free from Professor Moriarty.' 
The shift from translocation to change of state yields some very frequent collocations, such as tikt galā 'cope with' (literally 'get to the end of sth'), tikt skaidrība 'understand' (literally 'come into clarity') etc. See the example below and more examples to follow.

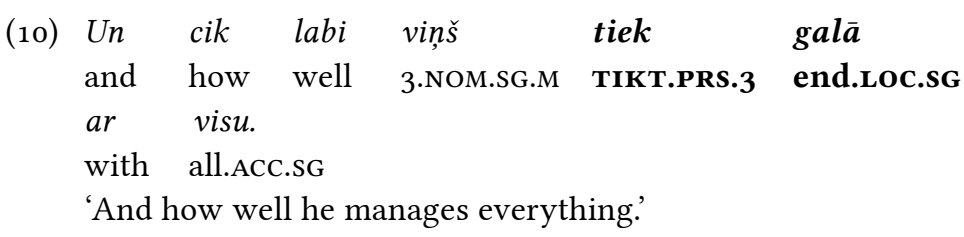

When combined with a recipient in the dative, the meaning of translocation is understood as inceptive possession.
(11) Dāvanas
tika
$\operatorname{ar} \bar{\imath}$ present.NOM.PL
mūziķiem.
'The musicians also got some presents.'
musician.DAT.PL
Literally: 'Some presents fell to the share of the musicians as well.'

A similar meaning, though with a different case frame (the possessor being encoded as subject), is expressed by a combination of tikt with a preposition pie followed by a noun in the genitive, which appears to be a further development of tikt pie + GEN in a purely spatial meaning, cf. the two examples below.
(12) $<\ldots>\quad$ cel̦
caur kuru
(13) Tie
kas
REL.NOM
nebaidās
riskēt,
DEM.NOM.PL.M
pie
NEG.fear.PRS.3.RFL
risk.INF
tiek
to
visādiem
labumiem.
TIKT.PRS.3
various.DAT.PL.M
benefit.DAT.PL
'Those who are not afraid of taking risks receive various benefits.'
A variety of this construction contains a verbal noun with the suffix -šan-, referring to a situation in which a person is brought by circumstances to exercise a certain type of activity: 


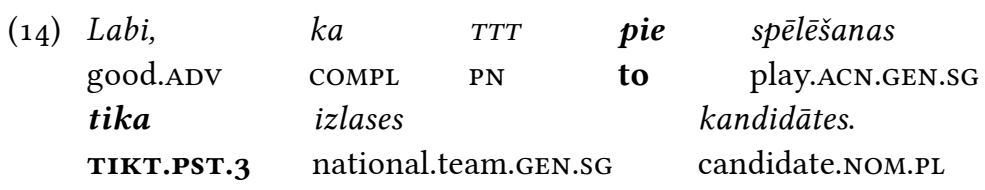

'It is a good thing that candidates for the national team got to play in the тTт tournament.'

Instead of this prepositional phrase with a verbal noun we also rarely find an infinitive, probably arising through deletion of the directional phrase and expansion with what was originally an infinitive of purpose, see Daugavet $(2015,35)$. At this stage we could call tikt an implicative complement-taking verb. An implicative verb (for this notion see Karttunen 1971) is a verb implying that the event expressed by the clausal complement actually takes place (or, if the implicative verb is negated, does not take place), and specifying the necessary and sufficient conditions for this event to take place.
(15) $<\ldots>$ uz tā
strādāt tiks
paši
on DEM.GEN.SG.M
work.INF TIKT.FUT.3
very.NOM.PL.M
labākie.
good.COMP.NOM.PL.M.DEF
' $<\ldots>$ it is the very best ones who will get to work on it [sc. a ship].'
(16)

$\begin{array}{lllll}\text { Svarigi, } & \text { lai } & \text { müsējie } & \text { tiek } & \text { spēèet. } \\ \text { important.ADV } & \text { COMPL } & \text { our.NOM.PL.M.DEF } & \text { TIKT.PRs.3 } & \text { play.INF } \\ \text { 'It is important that our people get to play.' } & & \end{array}$

Although formally tikt par + Acc contains a prepositional phrase, it only expresses change of state and is synchronically no longer felt to involve a spatial metaphor.

$\begin{array}{llll}<\ldots>\quad \text { laika } & \text { gaita } & t u \\ \text { time.GEN.SG } & \text { course.LOC.SG } & \text { 2SG.NOM } \\ \text { mācies } & \text { tikt } & \text { par cilvēku. } \\ \text { learn.PRS.2SG.RFL } & \text { TIKT.INF } & \text { PRED human.being.ACC.SG } \\ \text { '<...> you learn how to become a human being in course of time.' }\end{array}$

The expression is synonymous with $t i k t+$ NOM, where tikt is accompanied by a noun in the nominative case.

(18) [ [ $a$ arī visas, kas gribēja,]

$\begin{array}{ll}\text { netika } & \text { aktrises }<\ldots> \\ \text { NEG.TIKT.PST.3 } & \text { actress.NOM.PL }\end{array}$

'[Even if not everybody who wanted to] became an actress $<\ldots>$.' 
While tikt par + ACC is formally identical to prepositional phrases conveying translocation, a noun in the nominative is a feature that unites $t i k t+$ NOM with adjectival constructions. Both tikt par + ACC and tikt + NOM are rare in miljons-2.o, although they are more frequent in the Rainis corpus.

\subsection{Copular constructions}

There is no clear difference in meaning between adverbial and adjectival constructions expressing change of state, cf. the examples below.

(19) Viņš netika skaidrībā,

3.NOM.SG.M

NEG.TIKT.PST.3

clarity.LOc.sG

[vai tiek vests uz tiesu vai operāciju zāli.]

'He was unable to understand [whether he was being taken to a courtroom or to an operating theatre.]'
(20) Un tu
netiec
gudrs -
$k \bar{a} \bar{p} \bar{c}$.
and 2SG.NOM
NEG.TIKT.PRS.2SG
clever.NOM.sG.M why
'And you can't figure out why.'

The formal difference is that in adjectival constructions tikt combines with words that agree with the subject in gender and number.

Another frequent collocation of tikt and an adjectival complement has an adjective in the comparative form.

(21) [Te mēs sevi pazīstam kā tautu,]

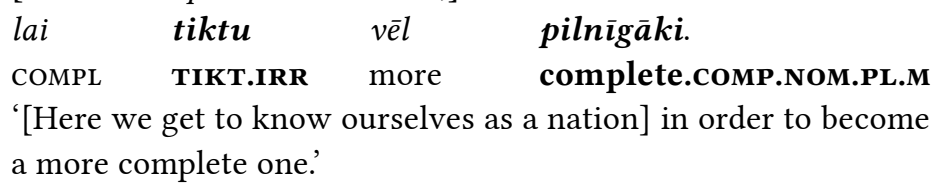

Although tikt + ADJ apparently reflects a transition towards analytical forms containing tikt as an auxiliary, it is rarely found in miljons-2.o, much like $t i k t+$ NOM and tikt par + ACC. All three constructions are however more common in the Rainis corpus, which means that they have fallen out of active use only recently. ${ }^{4}$

\footnotetext{
${ }^{4}$ This cannot be an idiosyncratic feature of Rainis' literary style because, as shown in Daugavet $(2015,56-57)$, a similar tendency manifests itself in a well-known text from the early 20 th century, Latviešu rakstniecības vēsture ('History of Latvian Literature') by Teodors Zeiferts (Vols. 1-2, 1922, 1930).
} 
There are two types of participles that combine with tikt as a kind of auxiliary to make up what looks like two different analytic forms. The first one, which is the most common use of tikt, is the actional (dynamic) passive. The use of the verb $b \bar{u} t$ 'be' instead of tikt turns the construction into a resultative (stative) passive - see Holvoet (2001, 161-166) for more details on the use of tikt and 'be' in passive constructions.

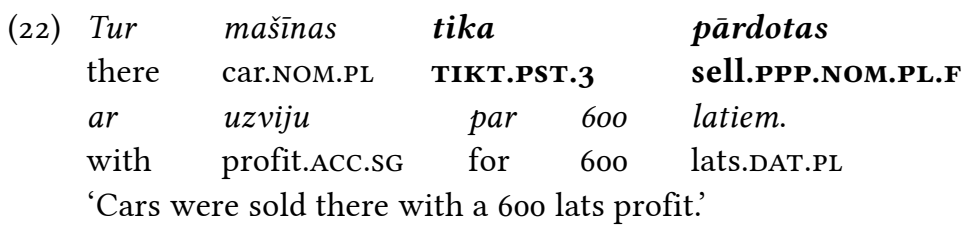
(23) $7 a$ ir pārdoti viltus jautājumi,
if $\boldsymbol{b} \bar{u}$ t.PRS.3 sell.PPP.NOM.PL.M deceit.gen.SG question.NOM.PL
[tā uzreiz ir krāpšana.]
'If the tests that have been sold are false, [this qualifies as fraud.]'

The use of tikt as an auxiliary with the actional (dynamic) passive was less widespread a hundred years ago when the alternative verbs tapt and $k l \grave{u} t$, both meaning 'become', were more frequently used instead (Nau \& Holvoet 2015, 10).

The second combination of tikt with a participle involves an active past participle producing a perfect-like form where tikt is found instead of the verb $b \bar{u} t$ 'be' which one would expect to appear with the genuine perfect. As was mentioned in the introduction, the important formal distinction from the perfect is that in $t i k t+$ PPA the auxiliary-like $t i k t$ is only found in the past tense whereas $b \bar{u} t$ in combination with the same participle can be used in any tense form yielding present perfect, past perfect, and future perfect forms respectively. See the examples with the present and the past perfect below.

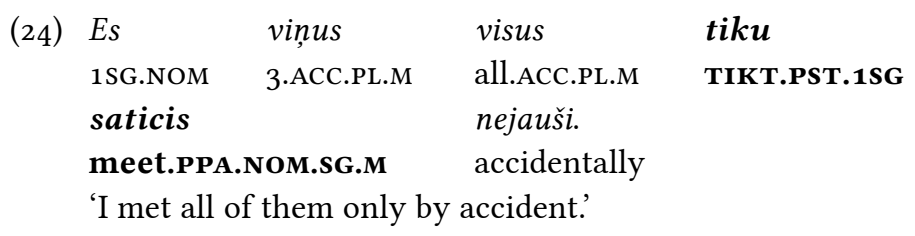
(25) Šad tad esmu saticis sometimes būt.PRS.1SG meet.PPA.NOM.sG.M domubiedrus.
like.minded.person.ACC.PL
'I have met like-minded persons at some points.'




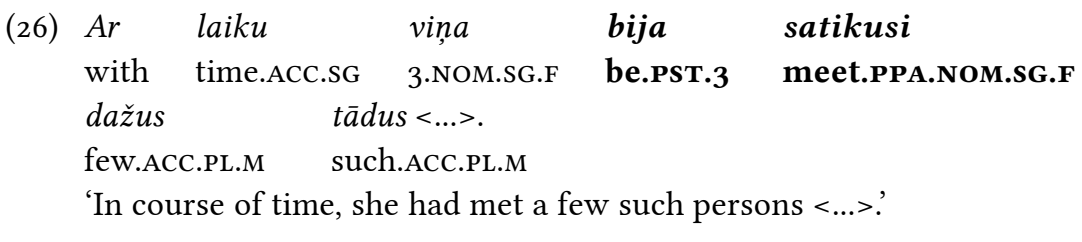

There is a superficial similarity between the alternative use of $b \bar{u} t$ and tikt with past active participles and the use of these two verbs as auxiliaries of the passive. As the passive with tikt is commonly referred to as actional passive in contradistinction to the stative passive with $b \bar{u} t$, the New Academy Grammar refers to tikt + PPA as the 'actional perfect' (Grigorjevs, ed., 2013, 480). This terminology is completely gratuitous: As there is no reason to regard the perfect with $b \bar{u} t$ as specifically stative, there is also no reason to view the construction with tikt as dynamic in contrast to it.

\subsection{Dialectal variation}

According to Anna Stafecka (p.c.), the construction involving tikt and an active past participle was not taken into account when collecting the data for the Latvian Dialect Atlas, but dialectologists agree that it can be found in High Latvian, including both Selonian and Latgalian (for the standardised variety of the latter $\mathrm{cf}$. Nau 2011, 50).

Map 1. Latvian dialects and regions referred to in the article

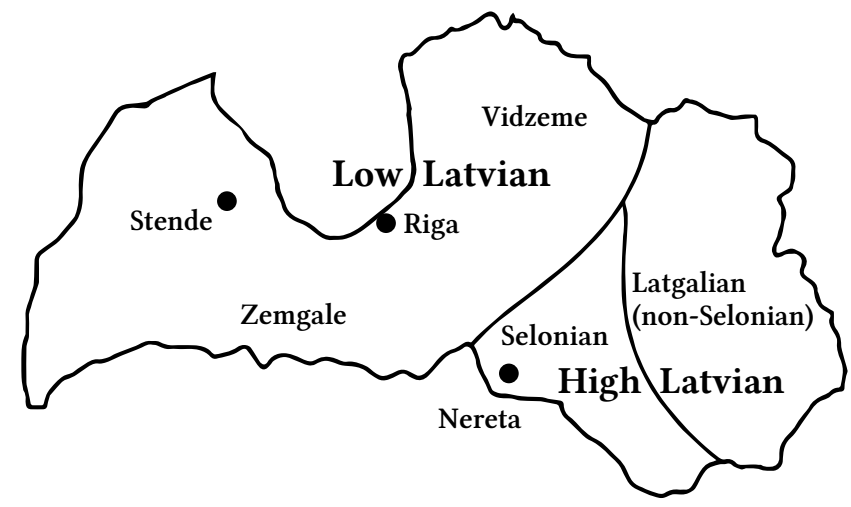

Evidence from those Latvian writers that were born in the 19th century allows us to include adjacent parts of the Low Latvian of Central Vidzeme in this area (Nicole Nau, p.c.). Among the numerous descriptions of dialects in the pre-war issues of the leading philological periodical Filologu Biedrïbas 
Raksti as well as several post-war publications, it is only in a subset of descriptions of High Latvian, especially Selonian, that the construction is mentioned. It is particularly striking that Rūkse and Draviňš (1958), the authors of the most detailed description of any Latvian dialect, say not a word about it in their monograph on the Low Latvian dialect of Stende.

Since the works referred to are concerned more with phonology and inflectional morphology, the construction is only briefly mentioned among regular examples of other analytical forms, especially past perfect. Only about half of the authors comment explicitly on the auxiliary tikt, and the examples are often too short to allow conclusions about meaning. The list of almost identical examples below (not all of them complete sentences) nearly exhausts the relevant data in the publications.

(27) Selonian dialect of Dignāja (Indāne 1986, 114)

$\begin{array}{llll}\grave{a} r \quad t u & \text { es } & n a: t y k u & \text { ploâvuśe, } \\ \text { with DEM.ACC.SG } & \text { 1SG.NOM } & \text { NEG.TIKT.PST.1SG } & \text { mow.PPA.NOM.SG.F } \\ \text { réżéjuśe } & t y k u & & \\ \text { see.PPA.NOM.SG.F } & \text { TIKT.PST.1SG } & \end{array}$

'I have not mown with it, but I have seen (it).'

(28) Selonian dialect of Sēlpils (Vīksne 1940, 71)

tiku bejuse

TIKT.PST.1SG be.PPA.NOM.SG.F

'I have been'

(29) Selonian dialect of Aknīste (Ancītis 1935, 190; 1977, 259)

es tyku bejś

1SG.NOM TIKT.PST.1SG be.PPA.NOM.SG.M

'I have been' (the author adds 'many times')

(30) Selonian dialect of Daudzese (Vìksne 1937, 158)

$\begin{array}{llll}\text { ês } & \text { jòu } & \text { natik }^{a} & \text { skùola } \\ \text { 1SG.NOM } \quad \text { PTC } & \text { NEG.TIKT.PST.1SG } & \text { school.LOC.SG } \\ \text { ni.viên }{ }^{a} & & \text { dien }^{a} & \text { gòajs } \\ \text { NEG.one.ACC.SG } & \text { day.ACC.SG } & \text { go.PPA.NOM.SG.M } \\ \text { 'I have not been to } & \text { school for a single } & \text { day' }\end{array}$

'I have not been to school for a single day'

Some dialects use an alternative indeclinable form -um (with a reflexive variety -um-ies) with both tikt and $b \bar{u} t$. This form is referred to as a participle (and is here glossed accordingly) but in origin it is probably a case form of a verbal noun in -ums (as assumed already by Mühlenbach $1905,410-12=2011,217-219)$ : 
(31) Selonian dialect of Sausnēja (Poiša 1985, 62)

$\begin{array}{llll}a ! s & \text { jòu } n a:-t \dot{y}: k & \text { bij-ùm } \\ \text { 1.SG.NOM PTC NEG-TIKT.PST } & \text { be-PTCP } \\ \text { 'I have not been [there]' } & \end{array}$

At least in one dialect (which also happens to belong to the Latgalian dialect group rather than the Selonian one as in the previous examples) tikt is claimed to be used in analytical forms with both past and present. As the author does not comment on function, it remains unclear whether there is any difference in meaning between (32a) and (32b) and whether (32b) should be translated with a past perfect form into English.

(32) High Latvian dialect of Liezēre (Hauzenberga 1934, 192)
a. nij tìek oizgàjs uz dor̂rbu nij '(They) have not gone to (their) workplace.' NEG TIKT.3.PRS go.PPA.NOM.SG.M to work.ACC.SG NEG
b. e̦s tiku sệệse
1SG.NOM TIKT.PST.1SG sit.PPA.NOM.SG.F
'I have (had?) sat'

In conclusion, we can say that the construction with tikt was originally a feature of part of the Latvian dialects, especially those of Selonia. It has, however, become a feature of the standard language, and the grammars (Endzelin 1923; Bergmane et al., eds., 1959; Grigorjevs, ed., 2013) do not even mention its restriction to part of the Latvian dialects.

\section{Description}

Taking into account the facts discussed in the previous section, we will now consider how the construction with tikt and the past active participle should be interpreted. As mentioned, Endzelin and the Academy grammars describe it as a tense form, but Endzelin translates it as 'es fügte sich' ('it thus happened') and compares it to Ancient Greek constructions with the verb tynchánō 'I happen to (be doing sth)', which also combines with participles:

(33) Ancient Greek

étychen hestēkós

happen.AOR.3SG stand.PPFA.NOM.SG.M

'he happened to be standing' 
This account suggests that tikt + PPA should (like the construction with the infinitive mentioned in section 4.1 ) be interpreted as an implicative verb, and the whole construction as consisting of a higher predicate and its complement. Whether tikt is to be interpreted as an auxiliary or a complement-taking higher verb can probably not be decided on the basis of purely semantic arguments, but at this stage we should point out three facts:

- the construction at hand exists alongside and independently of the implicative construction with tikt and the infinitive. There is a priori no reason to assume that implicatives should combine with the infinitive; Greek tynchánō, cited as a parallel by Endzelin, would be a good example of an implicative verb taking participial complements. But the two constructions would have to be somehow differentiated as they do not seem to stand in free variation. This suggests that $t i k t+$ participle is something different from the implicative construction 'happen to $+\mathrm{V}$ '.

- tikt is elsewhere treated as an auxiliary, viz. in combinations with passive participles; while this is, of course, not decisive for the interpretation of other constructions with tikt, it might show that this verb has a certain propensity for auxiliarisation;

- while the complement-taking implicative verb tikt is used in different tenses, the preterite tiku occurring in the construction at hand does not alternate with other tense forms, which suggests a specific kind of interaction with tense not characteristic of the implicative constructions with tikt and the infinitive, which show no such restrictions.

In accordance with the intuition of those linguists who have described the construction with tikt and the past active participle as a kind of tense form, we will investigate it on the assumption that its semantics can at least be compared with that of tense forms.

The examples with which, in this introductory section, we will attempt to give a preliminary characteristic of the use of the tense forms with tikt are taken from one single author. The reason is that, as mentioned above, this construction was originally restricted to one region of Latvia; its centre is constituted by the Selonian dialects. We have therefore singled out two texts by a writer native to this area, Jānis Jaunsudrabiņš (1877-1962), who was born in the civil parish of Nereta and had this gram in his na- 
tive dialect. Our assumption is that in the period in which Jaunsudrabiņš acquired his native language the written language reflected the dialectal substratum represented by the writer more faithfully than nowadays, and that in those writers who have the construction it is used as in the substratum dialect. By way of comparison, the bulky novel Rig $a$, by Augusts Deglavs (1862-1922), who was born in the civil parish of Škībe near Jelgava (Zemgale), does not contain a single instance of the construction. A modern Latvian writer might not have a native regional dialect and just use the construction with tikt because it is known to her/him as a feature of the standard language. Contemporary Latvian speakers who are in this situation must, of course, also have certain intuitions about the use of the construction, but these may not quite coincide with the original use in the regional dialects where it is indigenous; we will touch upon this question further on.

After a reconnaissance based on just one book by Jaunsudrabiņš, we will enlarge our empirical base including another text by this author; this will reveal new types of use which we will have to integrate in our description. In a next step, we will examine the use of our construction in Rainis (1865-1929). Like Jaunsudrabiņš, Rainis came from the area where our construction is indigenous. Owing to his status as a Latvian national writer, a digital corpus of his writing has been compiled. Importantly, this corpus also contains other text sorts apart from the narrative genre represented in Jaunsudrabiņš. It includes drama, poetry, publicistic texts and private correspondence. Rainis' data will reveal basically the same types of use, but different relative frequencies of the individual types according to genre. After that, we will switch to the modern language. As mentioned, the construction with tikt is recognised as a feature of the standard language, so it can potentially be used by speakers who have not necessarily inherited the construction from their native dialect. It should be mentioned that most speakers of modern Latvian do not have a native regional dialect, as the standardisation process has been rapidly extending since the establishment of the independent Latvian State in 1918. There is thus no longer any point in trying to establish where a person comes from. In examining the data of modern Latvian we will therefore take into account only text sort (genre). Here our sources will be miljons-2.o, which comprises basically narrative texts, and the Corpus of Saeima (Parliamentary) Proceedings, which reflects edited transcripts of oral speech. 


\section{A first reconnaissance based on Jaunsudrabiņš’ Baltā grāmata}

Jaunsudrabin̄š' book of childhood reminiscences Baltā grāmata 'The White Book' contains only a dozen instances of our construction, too few to get an accurate picture of its use but enough to illustrate the main types of use and to compare them with the remaining past tense forms of the Latvian verb. First, we find cases where the construction with tikt could be replaced with a perfect - to be more precise, an experiential perfect:

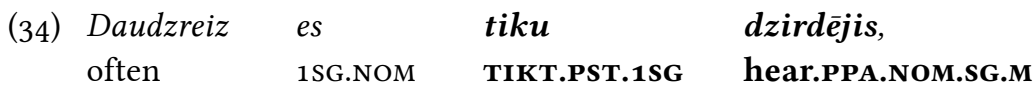
[ka siļ̧e un kartupelis esot tāds èdienu pāris, kurus tikpat labprāt èdot ubags, kā ķeizars.]

'Many times I have heard it said [that herring and potatoes are a pair of edibles that both a pauper and an emperor eat with equal relish.]'

It does not replace the resultative perfect, illustrated in sentence (35):

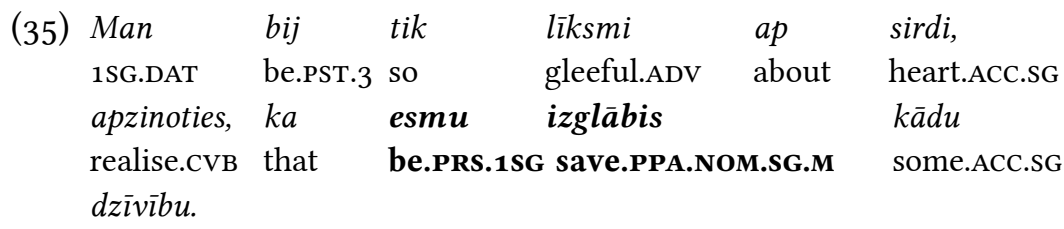

life.ACC.SG

'My heart felt so elated at the realisation that I had saved a life.'

However, the construction with tikt is not just a "restricted perfect" with the experiential functions characteristic of the prototypical perfect but without the resultative ones (the co-occurrence of experiential and resultative functions being a definitional feature of a true perfect, cf. Dahl $\&$ Velupillai 2013). It can also be used in contexts where it would have to be replaced with a pluperfect rather than a perfect. It is then also experiential as in (34), but it is shifted to the past, that is, reference time is in the past and does not coincide with the narrator's 'now'. This is observed in (36):

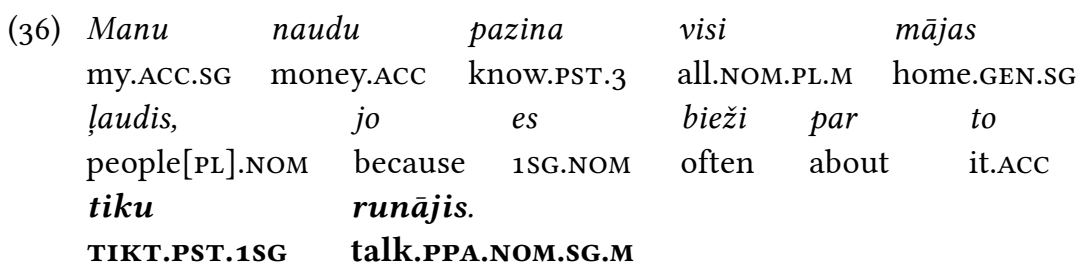

'The whole house knew about my 'money', for I had often been talking about it.' 
Finally, we also find uses where the substitution of either a perfect or a pluperfect for the construction with tikt would be impossible, and a simple past would be called for:

\begin{tabular}{|c|c|c|c|c|c|}
\hline $\begin{array}{l}\text { Iedoma, } \\
\text { fancy.NOM. }\end{array}$ & $\begin{array}{l}k a \\
\text { that }\end{array}$ & $\begin{array}{l}\text { galdiņš } \\
\text { table.DIM.NOM.SG }\end{array}$ & $\begin{array}{l}\text { varētu } \\
\text { could.IRR }\end{array}$ & \multicolumn{2}{|c|}{$\begin{array}{l}\text { man } \\
\text { 1SG.DAT }\end{array}$} \\
\hline & mani & tik stipri & nospieda, & & es \\
\hline st.INF & 1SG.ACC & strongly & PST.3 & that & 1SG.NO \\
\hline & & netiku & Jes & & \\
\hline C.SG & way. & חת & & M. & $\mathbf{S} . \mathbf{M}$ \\
\hline
\end{tabular}

'The thought that the little table could be lost to me depressed me so much that I didn't laugh a single time on the whole way [home].'

In this case the construction netiku pasmejjies could be replaced with the preterite nepasmejjos. The perfect would not be possible here because this sentence is part of a narrative. Reference time is therefore in the past, and it does not coincide with the narrator's 'now'. What the construction netiku pasmejjies seems to have in common with the perfect is the lack of reference to a specific moment. The form has negative existential function in that it is asserted there was not a single occurrence of laughing over the whole duration of the journey.

The contrast between the tikt-construction and the simple preterite can be seen from the following narrative sequence, which comprises the sentence analyzed in (37) and the follow-up sentence:

(38) [Iedoma, ka galdiņš varētu man zust, mani tik stipri nospieda, ka es visu ceļu netiku pasmējies.]

$\begin{array}{lllll}\text { Māte } & \text { redzēja } & \text { manas } & \text { bēdas } & \text { un } \\ \text { mother.NOM.SG } & \text { see.PST.3 } & \text { my.ACC.PL.F } & \text { sorrow[PL].ACC } & \text { and } \\ \text { teica, } k a & \text { cita } & \text { reize } & \text { man } & \\ \text { say.PST.3 that } & \text { other.LOC.SG time.LOC.SG } & \text { 1SG.DAT } & \\ \text { vajagot } & \text { prasit. } & & & \\ \text { be.needed.EVID } & \text { ask.INF } & & & \end{array}$

'[The thought that the little table could be lost to me depressed me so much that I didn't laugh a single time on the whole way home.] My mother saw my sorrow and said I would have to ask for it another time.'

The difference is in that the events in the follow-up sentence have an exact location in a narrative sequence: redzèja 'saw' presumably coincided with the duration of the drive but could also refer to a specific moment during the drive (as redzēja is aspectually vague), while teica refers to a 
specific moment during the drive. In Reichenbachian terms (see Reichenbach 1947) we could preliminarily say (this will have to be corrected later on) that in both cases reference time coincides with event time. In order to characterise netiku pasmējies in the preceding sentence we have to operate with an extended reference time which can be said to comprise a number of instances of the event, or to comprise none.

As already mentioned above, the construction with tikt has certain features of what Dahl calls experiential, cf. Dahl (1985, 139-144). According to Dahl's definition, "the basic use of EXPER is in sentences in which it is asserted (questioned, denied) that an event of a certain type took place at least once during a certain period up to a certain point in time." One of the questions on the basis of which it is identified is

Q: When you came to this place a year ago, did you know my brother? (No,) I not MEET him (before I came here but I met him later)

This would correspond to a pluperfect in those languages that have this category. In other words, Dahl's experiential is not a restricted perfect (i.e. a perfect restricted to experiential function), and neither is the Latvian construction with tikt. Dahl's questionnaire would cover two of the three types of use identified above for $t i k t+$ PPA, but the instances where it can be replaced with the simple past are somewhat problematic. Dahl's formulation "during a certain period" should capture uses as in (37) if we assume that this interval may be closed at both ends, but such situations are not covered by a specific question in Dahl's questionnaire. At any rate, the location within that interval is indefinite, and reference is made to a type of event, e.g., an instance of laughing.

The fact that the construction with tikt can correspond to three different tense forms means that the location of the event with regard to reference time $\mathrm{R}$ cannot be the same everywhere. This makes our tense form somewhat difficult to characterise in Reichenbachian terms. We will here attempt a characterisation that does not crucially rely on a certain relationship to $\mathrm{R}$ but tries to capture the similarity to the perfect in the sense of a certain indeterminacy of location on the axis of time through a specific relationship with event time $\mathrm{E}$.

As is well known, there has been some discussion on whether time adverbials with perfects are associated with reference time or event time. It seems reasonable to assume that the time adverbial coincides with reference time in (39) but not in (40): 
(39) I have now visited all countries of the world.

(40) Like all men of the Library, I have travelled in my youth.

In (40) reference time encompasses speech time, as the subject's experiences are being referred to as determining her/his state of consciousness. But the event itself is tied to a time frame clearly separated from the time of speech.

If we equate this time frame with event time, we must dissociate event time from the trace of the event on the axis of time, a solution also suggested by Kiparsky (2002) in his account of the experiential (in his terminology, existential) perfect. Kiparsky defines its meaning as the inclusion of $\varepsilon$, defined as the temporal trace of the event denoted by a predicate, in event time. Kiparsky goes on to say that "the event does not have to extend throughout the entire interval E [...] and the implicature is that it does not". Applied to example (37), the duration of the journey defines event time E, which is said to include no instantiation of the event.

Kiparsky's neo-Reichenbachian account of the experiential perfect is shown in the following diagram, in which $\mathrm{P}$ is what Kiparsky calls "perspective time", a generalised notion subsuming speech time but allowing for narrative shifts etc. The arrow symbolises inclusion:

Figure 1. Reichenbachian schema for the experiential perfect (from Kiparsky 2002)

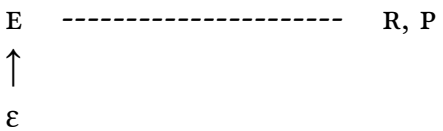

Kiparsky's schema can naturally be modified to accommodate situations where the construction with tikt corresponds to an experiential pluperfect:

Figure 2. Reichenbachian schema for the pluperfect-like uses of tikt $+P P A$

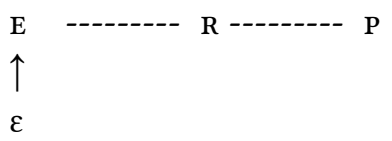

And, finally, by letting reference time coincide with event time, we can account for those uses where the construction with tikt can be replaced with a preterite: 
Figure 3. Reichenbachian schema for the preterite-like uses of tikt $+P P A$

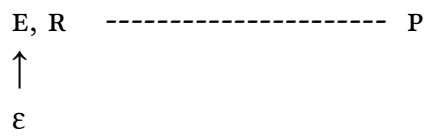

The relation of inclusion rather than coincidence might be the feature crucially opposing the construction with tikt to the narrative preterite, where the trace of the event is not distinct from event time.

The relation of inclusion says nothing about the number of instantiations of the event. The examples from Jaunsudrabiņš’ Baltā grāmata have in common that the construction with tikt refers to more than one occasion when an event of a certain type took place during a certain period in the past. In fact, the iterativity of the situations they describe is overtly expressed by the adverbs daudzreiz 'many times' (34), nez cik reižu 'God knows how many times', bieži (vien) 'often' (36) and even retu reizi 'rarely'. Where a corresponding adverb is absent, the iterativity can be inferred from other elements of the context, cf. (41), where the mention of many agents forces an iterative reading:

(41) [Cik labprāt atceros visus tos laudis,]

$\begin{array}{lllll}\text { kuri } & \text { to.reiz } & \text { bij } & \text { ap mani un } & \text { un } \\ \text { REL.NOM.PL.M } & \text { that.time be.PST.3 } & \text { around 1SG.ACC and } \\ \text { tika } & \text { ar } \quad \text { mani } & \text { runājuši } & \\ \text { TIKT.PST.3 } & \text { with 1SG.ACC } & \text { talk.PPA.NOM.PL.M } & \\ k \bar{a} d u & v \bar{a} d u . & & & \\ \text { INDEF.ACC.SG } & \text { word.ACC.SG } & & \end{array}$

'[It is with great pleasure that I recall all those people] who used to surround me and have (at some time) exchanged a few words with me.'

In questions as well as in sentences with negation the iterativity is potential, as they refer to many situations where a certain event could have taken place ( $k \bar{a} d r e i z$ 'any time', nevienam 'to no one' each corresponds to one/none out of many occasions/persons).

(42) [Bet jūs domājat,]

ka kād.reiz tika kas

COMPL any.time TIKT.PST.3 INDEF.NOM.SG

zudis?

disappear.PPA.NOM.SG.M

'Do you think that anything ever disappeared at any time?' 


$$
\begin{aligned}
& \text { (43) <... es par notikumu netiku } \\
& \text { 1SG.NOM about event.ACC.SG NEG.TIKT.PST.1SG } \\
& \text { teicis nevienam ne pušplēsta } \\
& \text { say.PPA.NOM.SG.M nobody.DAT NEG torn.in.two.GEN.SG.M } \\
& \text { vārda, } \\
& \text { word.GEN.SG } \\
& \text { [un, ja es to tagad daru, tad tikai tāpēc, ka solìtās algas vēl neesmu }
\end{aligned}
$$

Another feature shared by almost all of the examples from Baltā grāmata is that (potentially) recurring events of a certain type are repeated over a period of time that has no clearly marked boundaries. While the end of this period implicitly coincides with the time of reference, its beginning may go back as far as the subject's birth, thus comprising their whole life.

There are, however, two examples that are not entirely in agreement with these two observations. The first one is (37), here repeated as (44), in which the (potentially) recurring events are restricted to the time of the journey:

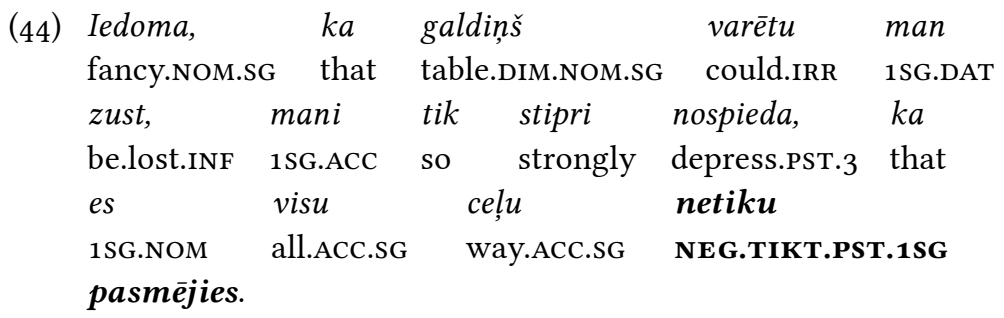

\section{laugh.PPA.NOM.SG.M.RFL}

'The thought that the little table could be lost to me depressed me so much that I didn't laugh a single time on the whole way [home.]'

The second example is ambiguous. Although the sentence may refer to the period beginning with the promise to pay and ending with the time of reference (compare (43) above), an alternative interpretation is also possible to the effect that the respective period comprised only a short time following the promise. Moreover, due to its briefness, the number of potential occasions when the promised action could have taken place is also reduced to the extent that there might have been only one such occasion. 


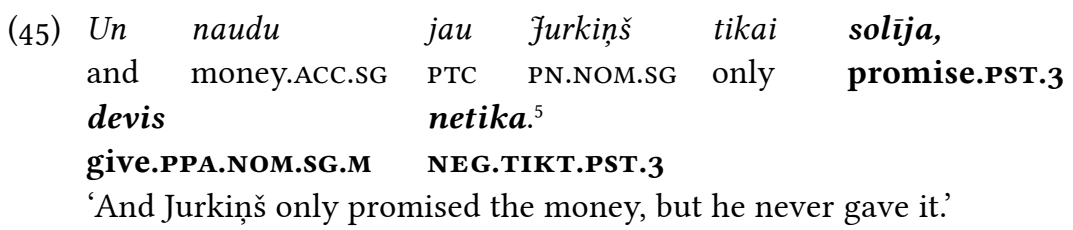

Although the evidence of these two examples, pointing to more specific time reference, may appear unconvincing when viewed against the rest of the data from Balta grāmata, there are more such cases in other texts by Jaunsudrabin̄š.

\section{Jaunsudrabiṇš: Zaḷā grāmata}

There are about 40 instances of the construction with tikt in Zaḷa grāmata 'The Green Book', which is a sequel to Baltā grāmata, and at least several of them are not iterative. An individual event is often placed inside a clearly defined period of time that is considerably shorter in comparison with the indefinite period of time referred to in most sentences from Baltā grāmata. Those examples from Zaḷa grāmata that convey individual events either contain corresponding adverbials (vienu vienīgu reizi 'one single time', $k \bar{a} d r e i z$ 'once') or define an interval of time with the aid of such adverbs as pavasarī 'in spring', pērn 'last year' or by pointing to simultaneous situations expressed by converbs and other clauses which, in some cases, may also correspond to individual events. But in many such examples, individual events actually appear as representatives of a certain type rather than a specific occurrence. In other words, they are still type-focusing rather than token-focusing, see Dahl \& Hedin $(2000,387)$ for the terms:

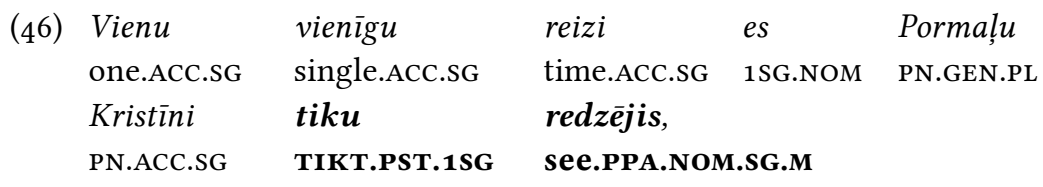

\footnotetext{
${ }^{5}$ See the broader context: "Jurkiņš felt sorry for his new machine but not for our horse. Once he came very close to me and said in a quiet voice: 'I'll give you three kopecks, just don't drive so hard.' He was ashamed of asking the landlord to allow us to work slower. But what could I do? I was scolded as soon as I gave the horse free reins. And as for the money, Jurkiņš only promised but never gave it."

${ }^{6}$ In (42) above kädreiz receives the meaning 'any time' due to the sentence being a question.
} 
[kaut gan dzirdējis biju par vin̨u bieži.]

'I saw Pormal̦u Kristīne only once [although I had heard of her often].'

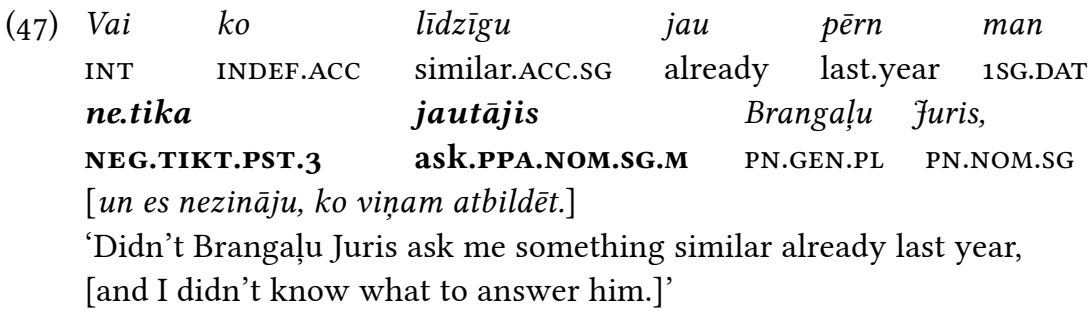

Now that we have introduced the distinction, it would not be out of place to observe that in most examples with negation as well as in questions, from both Baltā grāmata and Zaḷa grāmata alike, the distinction between a single event and multiple events is actually blurred. See (42) and (43), which were previously described as implying 'potential iterativity'.

The need to differentiate between individual events and series of repetitive events arises because some individual situations can only be interpreted from a token-focusing perspective, that is, as genuine unique events rather than representatives of a type. Although infrequent, they are still present in Zaļā grāmata as illustrated by the following examples.
(48) Māte
man
pavasarī
tika
mother.NOM.SG 1SG.DAT
spring.LOC.SG
TIKT.PST.3
teikusi,
say.PPA.NOM.SG.F
[kad es rādīju tulznainās delnas un teicu, ka tas no rakšanas, - redzēšot gan, kad nākšot āboḷi gatavi, vai es par savām tulznām dabūšot kādu sasu?] 'My mother told me in the spring, [when I showed her the calluses on my hands and explained that they were from digging, that she would see if I couldn't get a few apples for my trouble as soon as they got ripe.]'
(49) Es

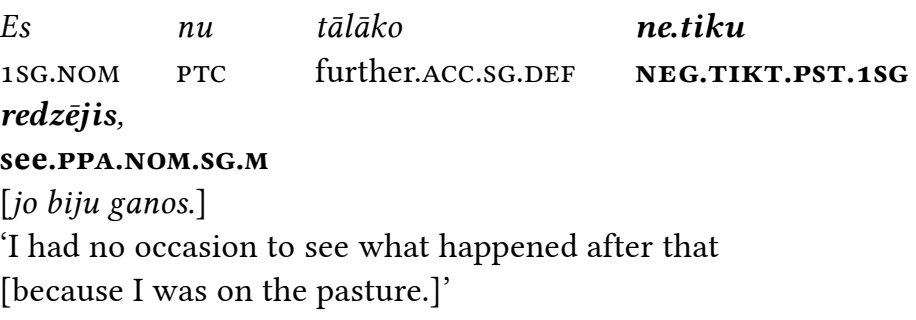

In some sentences the choice between a type-focusing or token-focusing perspective depends on whether the event is perceived as repetitive or 
unique. It is not clear if the mother's words in (50) were only uttered once during one of her visits or whether they represent her favourite saying at that time.

(50) [Pa reizai māte gan uz Liepiṇām atnāca. Ar saimnieci viņas bija tā kāa draudzenes kḷvušas, tā bērna dēḷ;]

jo māte pati tika

because mother.NOM.SG self.NOM.SG.F TIKT.PST.3

teikusi par savu ciemošanos:

say.PPA.NOM.sG.F about RPOSS.ACC.SG visit.ACN.ACC.SG.RFL [«Iegribējās Mikiņu redzèt, ne jau tevi. Tu esi liels. Kā par bèrnu vairs par tevi nevar priecāties. <...»》]

'[But my mother sometimes did come to Liepini. She became kind of friends with the landlady, because of the child.] Because my mother used to say / said herself about her visits: ['It's Mikinšs I wanted to see, not you. You are big. One cannot feel joy at your sight as of that of a child anymore. $<\ldots>^{\prime}$ ]'

\section{What we learned from Rainis}

Another author representative of the above-mentioned dialect area is Jānis Rainis (1965-1929), who was born in the Dunava civil parish. The current analysis is based on all 161 instances of tikt + PPA that are found in the corpus of his writings. The use of tikt + PPA in Rainis is, on the whole, in accordance with the results obtained from Baltā grāmata and Zaḷa grāmata by Jaunsudrabiňš.

Firstly, $t i k t+$ PPA can be replaced with either a perfect (51) or a preterite (52), although examples where tikt + PPA can be replaced with an unambiguous pluperfect are harder to find (53):

(51) [Tā mēs, piecpadsmit gadus dzīvodami pie pašas Itālijas robežas, Romu neredzējām.]

\begin{tabular}{lrlll} 
Kam & to & tiku & \multicolumn{2}{c}{ stāstījis, } \\
REL.DAT & DEM.ACC.SG & TIKT.PST.1SG & tell.PPA.NOM.sG.M \\
tas & tikai & galvu & vien & nokratija. \\
DEM.NOM.SG.M only & head.ACC.SG & PTC & shake.PST.3
\end{tabular}

'[Thus, while we lived at the Italian border for fifteen years, we never saw Rome.] Those whom I have told about this only shook their heads [in disbelief].' 
(52) [Elektriska bādes aparāta te Lugānā nau;]

$\begin{array}{llll}\text { Cìrihā } & \text { pie dakt<era> } & \text { Ostersetzeres } & \text { es } \\ \text { Zurich.LOC.SG } & \text { at doctor.GEN.SG Ostersetzer.GEN.SG } & \text { 1SG.NOM } \\ \text { tiku } & t \bar{a} d u s & \text { lietojis } & \text { gadiem. } \\ \text { TIKT.PST.1SG } & \text { such.ACC.PL } & \text { use.PPA.NOM.SG.M } & \text { year.DAT.PL }\end{array}$

'[There is no electric bath here in Lugano;] at Dr Ostersetzer's in Zurich I used them for years.'
（53） Tiku
iecerējis
daudzus
TIKT.PST.1SG
conceive.PPA.NOM.SG.M
many.ACC.PL.M
isus dzejolus,
short.ACC.PL.M poem.ACC.PL
[bet man nebija vairs spēka tos izstrādāt tālāk<... ]
'I (had) conceived many short poems [but I didn't have enough strength to work on them any further $<\ldots>$ ]'

Secondly, Rainis contains sentences that convey a certain type of events recurring over an extended period of time with no clearly marked boundaries, see (51) above. As in the examples from Jaunsudrabiňš, the iterativity of the event may be conveyed by the mention of multiple agents and/or multiple objects.

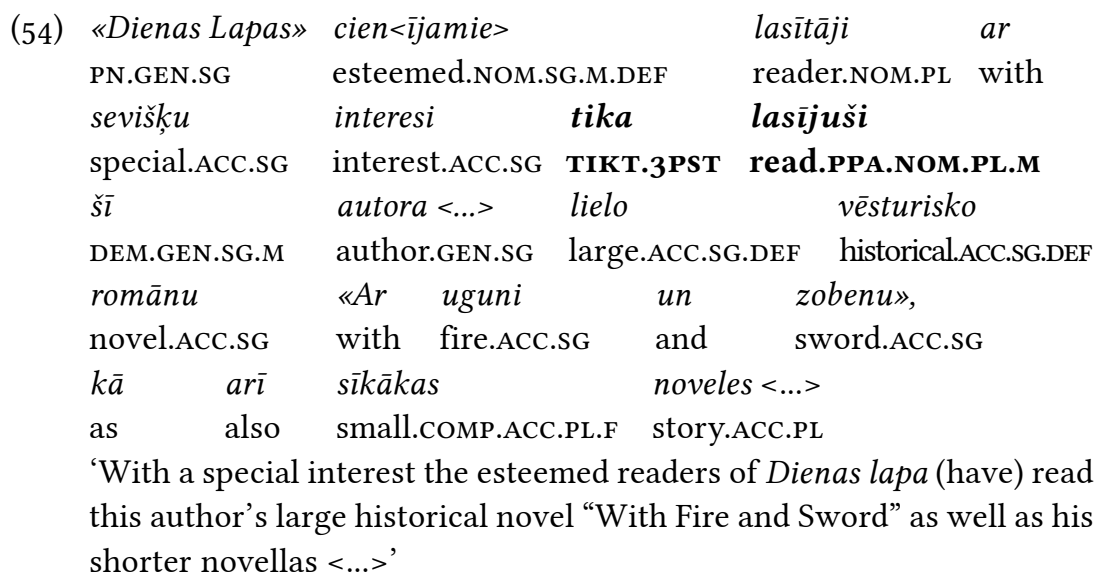

Since Rainis yields more data in comparison with the two books by Jaunsudrabin̄š, it has a greater diversity of predicate types including not only recurring events but also states that continue to hold at several points over a longer period of time. 


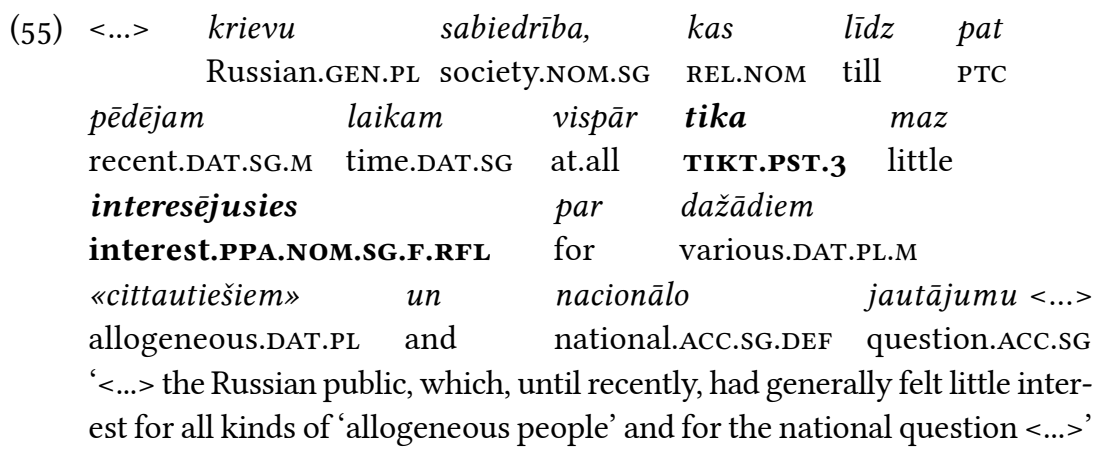

A time frame for recurrent events may last just for a clearly defined time span demarcated by calendar dates or by events characterising it, which is rather a typical context for preterites in general.

$$
\begin{aligned}
& \text { (56) }<\ldots>\text { 1923. gadā tiku pie tā } \\
& 1923 \text { year.LOC.SG TIKT.PST.1SG on DEM.GEN.SG } \\
& \text { diezgan daudz strādājis. } \\
& \text { quite much work.PST.PPA.NOM.sG.M } \\
& \text { 'I worked quite a lot on this in 1923.' }
\end{aligned}
$$

But many examples from Rainis refer to individual, situationally anchored events rather than to series of events, and we must discuss these in greater detail.

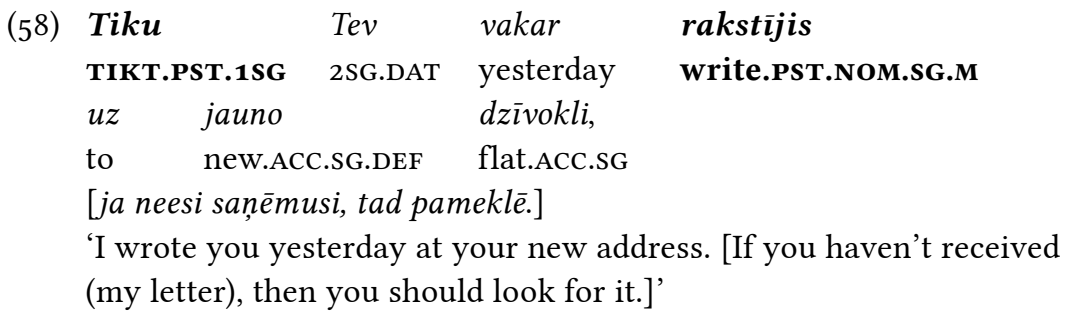

Negation may mean that a certain individual, situationally anchored (e.g., expected) event did not occur: 


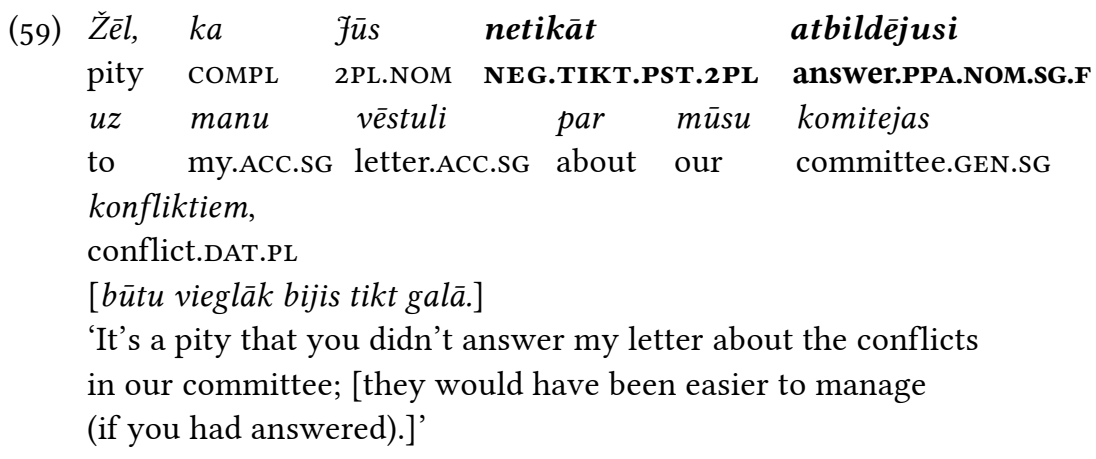

That the relationship between the type/token distinction and the iterativity of the event is not straightforward is further confirmed by the fact that one can find series of events in token-focusing sentences:

(6o) [Jelgavā tika arī iesākts Aspazijas «Saules meitas» tulkojums,]
un pie tā tiku strādājis,
and at DEM.GEN.SG.M TIKT.PST.1SG work.PPA.NOM.SG.M
[ kkā redzu no atzìmēm, maija, jūnija un jūlija mēnešos 1896. gadā <...>]
'[In Jelgava the translation of Aspazija's Daughter of the Sun was
commenced as well,] and I worked on it [in May, June, and July 1896, as I can see from my notes <..> ].'

It is impossible to establish for some examples whether they refer to individual situations or to series of repetitive events.

\begin{tabular}{|c|c|c|c|c|}
\hline (61) & $F r<i c i>$ & Bergmani & tiku & Pēterpilī \\
\hline & $\begin{array}{l}\text { PN.ACC.SG } \\
v \bar{e} l \\
\text { still }\end{array}$ & $\begin{array}{l}\text { PN.ACC.SG } \\
\text { saticis. } \\
\text { meet.PPA }\end{array}$ & TIKT.PST.1SG & Petrograd.LOc.sG \\
\hline
\end{tabular}

'I had occasion to meet Fricis Bergmanis in Petrograd.'

The type-focusing sentence (61) is concerned with the fact that Bergmanis was still in Petrograd when Rainis arrived there so that it was possible for Rainis to meet him. The number of occurrences is irrelevant, as a reference to one individual event may also be type-focused.

However, we also find instances where the indeterminacy between single event or series of events is an instance of ambiguity rather than vagueness. This can be seen in (62):

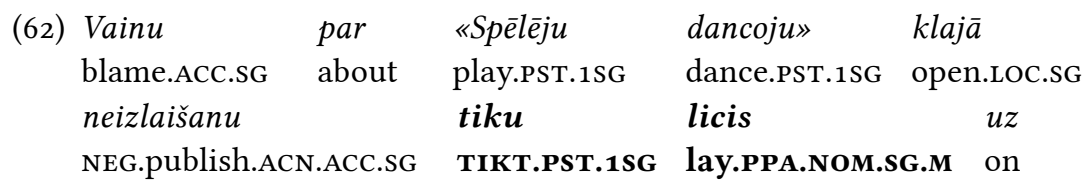




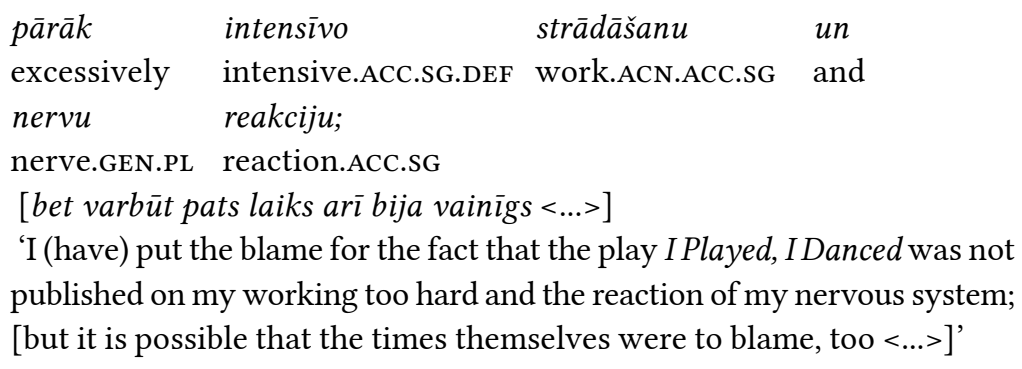

One of the possible readings of this sentence is that Rainis blamed the delay in publication on his nerves on a particular occasion which both the author and the reader remember (the other reading being repeated utterances in the same spirit). It is with respect to such uses that the data from Rainis differ from Jaunsudrabiņš. The distinction lies in the proportion of sentences conveying a series of events vs individual events. While the majority of Jaunsudrabiņš’ examples refer to series of events, this is not the case in Rainis, where examples of individual events are actually more frequent in comparison to either repetitive events or those sentences that are vague between iterative and type-focusing use. This difference is even reflected in the relative frequencies of adverbs. While the most common adverbs in Jaunsudrabiņš' books have the meaning 'many times' or 'often/rarely', the data from Rainis more often contain reference to time as measured by calendar and clock, e.g. vakar 'yesterday', pagājušo nakti 'last night', februarī 'in February' (although 'many times' and 'often/rarely' are found in Rainis as well).

Therefore, since individual situations do not necessarily entail a tokenfocusing reading, type-focusing examples still form the larger part of the data in Rainis. Nevertheless, token-focusing examples are much more common in Rainis than in Jaunsudrabinšs. Our explanation is that the majority of texts that yield the construction in Rainis consist of Rainis' letters, which are sometimes reminiscent of a dialogue. Typically, Rainis confirms that he did what was expected of him, as in the example below:

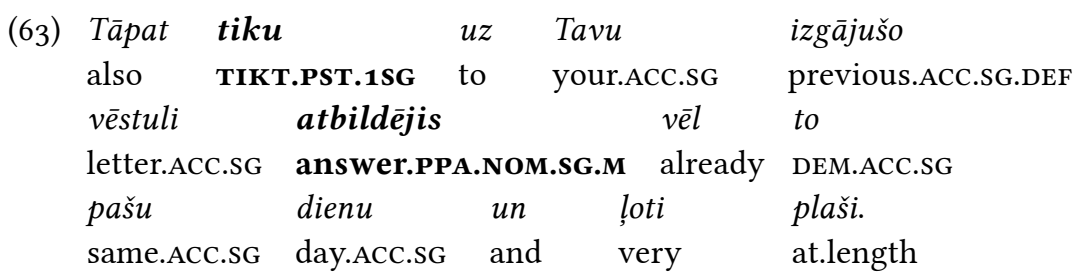

'Also, I answered your previous letter on the same day, and at great length.' 
Such examples are less likely to be found in a narrative, which accounts for their absence in Jaunsudrabiņš’ books. Jaunsudrabiṇš’ texts consist of narrative episodes interspersed with retrospective generalisations abounding in type-focusing uses. The more dialogic style of Rainis' correspondence contains numerous mentions of past events located within a very narrow time frame, e.g., a particular day. The most characteristic context is what Mehlig (2013) calls 'confirmative contexts': the reference is to a situationally anchored event that was often expected and that is considered abstracting away from its result (a typical example would be that of a letter that was not received but may or may not have been sent). This type of use corresponds to what is called the 'factual imperfective' in Russian aspectology (for a thorough study of this phenomenon cf. Grønn 2003). The experiential tense widens here to a kind of non-resultative nonnarrative past, a tendency noted by Dahl (1985, 143-144), who also raises the question whether such a non-resultative past is still a subtype of the experiential or whether it should be recognised as a distinct gram-type. Perhaps the fact that Latvian also shows this development constitutes a piece of evidence confirming that there is a natural tendency for experientials to develop such uses.

\section{What we can learn from modern texts}

Modern Standard Latvian is represented in our article by two different sources. Fiction and non-fiction texts written in the last decade of the 2oth century are found in the miljons-2.o corpus. The spoken language is represented by transcripts of sessions of the Latvian Parliament from the last decade of the 2oth century up to 2018, collected in the Saeima corpus. Although the transcript might have undergone some editing in comparison to the spoken original, we believe it highly unlikely that this kind of editing could have involved changes in the way in which tikt + PPA is used.

\subsection{Miljons-2.o}

The number of examples of tikt + PPA is about 50, which is actually comparable to the number of examples in Jaunsudrabiņš' Zaḷa grāmata alone. In other terms, it amounts to 14 per mln words, which is a noticeably smaller number than the 107 instances per mln words found in Rainis. It is enough to characterise tikt + PPA as an uncommon expression in modern Latvian 
literary texts. Nevertheless, the construction as it is found in modern written texts shows a certain continuity with regard to Jaunsudrabiňš and Rainis in that it may correspond to the three tenses mentioned above: perfect (64), pluperfect (65) and preterite (66).

(64) [Piecdesmit kilogramu smagā darba "Siren" (Sirēna) autors ir mākslinieks Marks Kvins,]

$\begin{array}{llll}\text { kurš } & \text { jau } & \text { iepriekš } & \text { tika } \\ \text { REL.NOM.SG.M } \quad \text { already } & \text { before } & \text { TIKT.PST.3 } \\ \text { veidojis } & & \text { Mosas } & \text { skulptūru. } \\ \text { create.PPA.NOM.SG.M } & \text { Moss.GEN.SG } & \text { sculpture.ACC.SG }\end{array}$

'[The author of the sculpture Siren, which weighs $50 \mathrm{~kg}$, is visual artist Marc Quinn] who has already created a sculptural portrait of Moss.'

(65) [Tā bija skaistākā dabas glezna,]

$k \bar{a} d u$ jebkad tiku redzējis.

REL.ACC.SG ever TIKT.PST.1SG see.PPA.NOM.SG.M

'[It was the most beautiful landscape] I had ever seen.'

(66) [Šai laikā es centos iekšēji sakārtoties un noskaidrot, kas tad man ìsti ir svarīgi.]

$\begin{array}{llll}\text { Tiku } & \text { savus } & \text { secinājumus } & \text { rūpīgi } \\ \text { TIKT.PST.1SG } & \text { RPOSS.ACC.PL.M } & \text { conclusion.ACC.PL } & \text { diligent.ADV } \\ \text { pierakstījis } & & \text { blociņă. } & \\ \text { write.down.PPA.NOM.SG.M } & \text { notepad.LOC.SG } & \end{array}$

'[At the time I tried to bring my inner world into order and find out what was really important for me.] I diligently wrote down my conclusions on a notepad.'

Most frequently the construction in miljons-2.o serves to convey actions that are repeated regularly over an extent of time which usually coincides with a person's whole life or a long period in it. Predicates in such sentences may also describe states that hold at many points over a longer period.

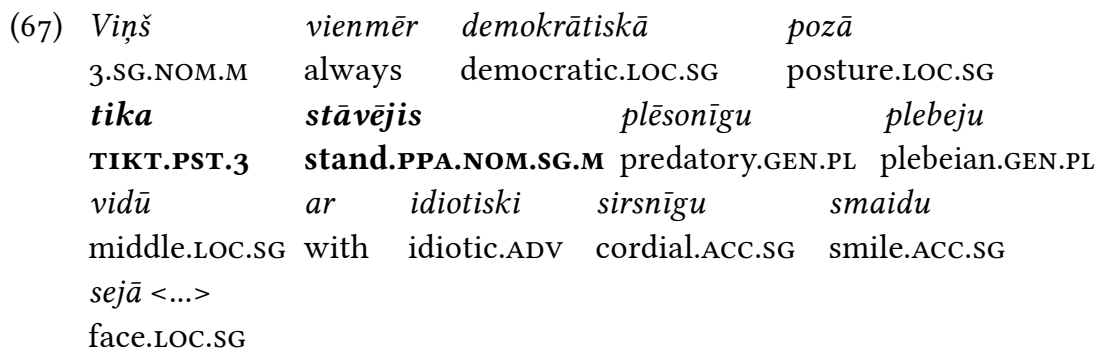


'He was always standing among predatory plebeians, his posture that of an advocate of democracy, with an imbecilically cordial smile on his face $<\ldots>$ '.

(68) [<...> kādu laiku pēc tam, kad biju dabūjis ar pagali pa galvu, es dzīvoju loti harmoniski.]

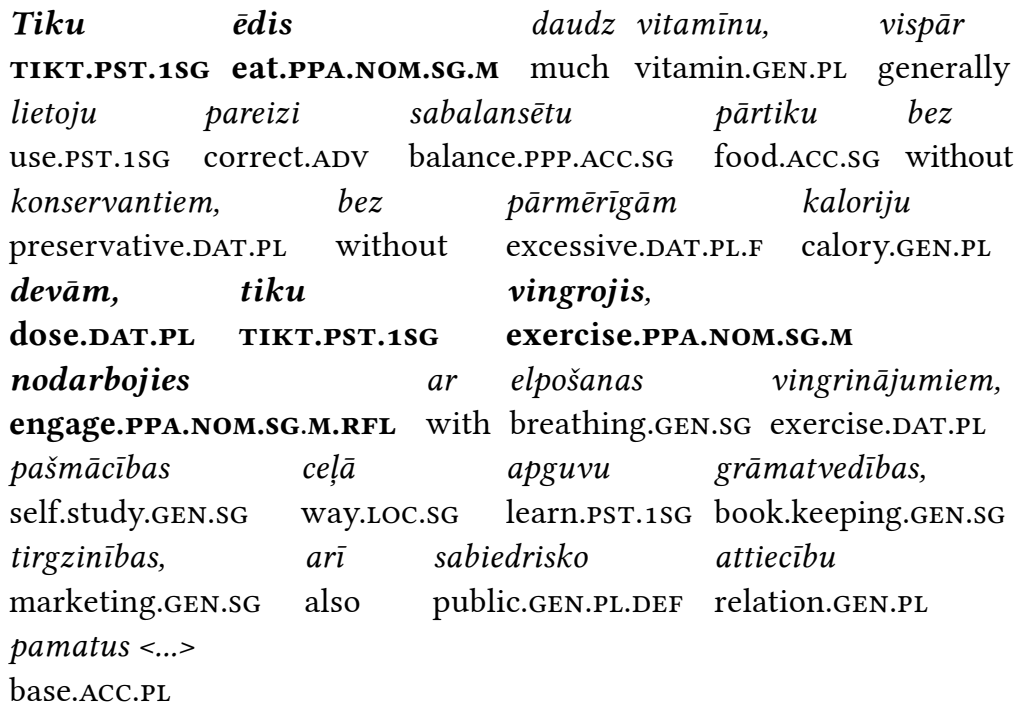
' $[<\ldots>$ after being hit on the head with a stick, I lived a very harmonious life for some time.] I ate a lot of vitamins; I consumed only well-balanced food without chemicals, and without excessive calories; I did gymnastics, and performed breathing exercises; I learned the basics of bookkeeping, marketing and PR all on my own $<\ldots>$ '

This text fragment nicely shows the functional differentiation of tense forms: tiku èdis, vingrojis, nodarbojies are type-focused, whereas apguvu is resultative (it refers to a skill acquired over the whole of the relevant period) and lietoju refers to a situation explicitly stated to have held over the whole reference time, as shown by the adverbial vispār 'overall, in general'.

\footnotetext{
${ }^{7}$ Although the repetition of the construction within a sentence may seem unusual, the use is quite authentic as a similar example is found in the Rainis corpus: <..> ar Ed. Volteri daudz tiku kopā strādājis ne vien pie viņa etnogrāfiskiem darbiem par latgaļiem, bet arī par leišiem; tiku norakstījis gabaliem un lasījis korektūru, piem., cik atminos, Daukšas «Postilla»; tur tiku lasījis arī senprūšu «Stas Dröffs»< _..> '< ..> I worked a lot with Ed<uard> Wolter not only on his ethnographic studies about Latgalians, but about Lithuanians as well; I copied large portions and read proofs, for example, of Daukša's Postilla; I also read the Old Prussian Stas Dröfs there <...>
} 
In comparison to both Rainis and Jaunsudrabiņš, miljons-2.o does not contain examples with adverbs meaning 'many times' or 'often/rarely', although the effect may be due to the limited size of the corpus. Miljons2.o, however, does have adverbs like 'once' or 'twice' in combination with tikt PPA, pertaining to individual occurrences of certain type of events. All these are type-focusing sentences.

(69)

\begin{tabular}{|c|c|c|c|}
\hline Varbūt & $k \bar{a} d \bar{a}$ & brīdì & tiku \\
\hline maybe & INDEF.LOC.SG & moment.LOC.sG & TIKT.PST.1SG \\
\hline
\end{tabular}

3.SG.DAT.M ring.up.PPA.NOM.SG.F

'Is it possible that I rang him up at some moment?'

(70) [Neizprotamā kārtā atcerējos,]

ka pāris reižu Rainim tiku

COMPL couple time.gEN.PL Rainis.DAT.SG TIKT.PST.1SG

iespēris

kick.PPA.NOM.sG.M

[-ne jau stipri, tikai drusku, lai norādìtu stulbajam zvēram tā vietu.]

'[Inexplicably, I remembered] that I had kicked Rainis ${ }^{8}$ a couple of times. [Not very hard, just lightly, to put the stupid beast in its place.]'

Token-focusing sentences are not so frequent in miljons-2.o as in Rainis, but still they are not so rare as in Jaunsudrabiņš’ texts either.

(71) [Nevarēdams aizmigt, Ėriks pēkšņi atcerējās,]

ka viņš pirms braukšanas jakas

COMPL 3.NOM.SG.M before going.GEN.SG jacket.GEN.SG

iekškabatāa tika ielicis piezīmju

inner.pocket.LOC.SG TIKT.PST.3 put.in.PPA.NOM.SG.M note.GEN.PL grāmatiņu ar savu sapņu

book.DIM.ACC.SG with RPOSS.GEN.PL dream.GEN.PL

aprakstiem <...>

description.DAT.PL

'While struggling to fall asleep, Eriks suddenly remembered that before leaving he had put his notebook in which he wrote down his dreams, into an inner pocket of his jacket $<\ldots>$ '

Neither token- nor type-focusing sentences in miljons-2.o contain reference to a fixed time in terms of months, days, hours etc., which is common

\footnotetext{
${ }^{8}$ In this case, not the distinguished writer but a cat.
} 
in Rainis but is rare in Jaunsudrabiňš' books. The only exception is, in fact, a citation from the Saeima proceedings, also found in the Saeima Corpus:
(72)
Šo.ruden vē
this.autumn vo
mandātu
mandate.Acc.sG
politikas
pēctecībai,
tika
devuši
politics.GEN.SG
succession.DAT.SG
ilg.laicīgai
stabilitātei
un
prognozējamiem
give.PPA.NOM.PL.M
and
predictable.DAT.PL.M
lèmumiem.
'This autumn the voters have given a mandate to the continuity of policy, long-term stability and predictable decisions.'

Interestingly, this and other sentences in miljons-2.o may have resultative readings, which will be discussed in the section on the Saeima Corpus.

\subsection{The Saeima Corpus}

Saeima has the largest number of examples with tikt + PPA amounting to about 450 , but the number of instances is due to the large size of Saeima itself $(17.5 \mathrm{mln})$, the number of $t i k t+$ PPA per mln being of the same order as the corresponding number for miljons-2.o (26 and 14 respectively). The Saeima Corpus (Saeima) is reminiscent of Rainis in that it contains speech that is intended as dialogue rather than narrative, the latter being characteristic of both Jaunsudrabiņš and miljons-2.o.

What sets Saeima apart from the other data is that no fewer than half of the tikt + PPA examples convey individual events, the share of tokenfocusing sentences also being about half of the data. This is even more than found in Rainis, and the explanation is twofold. Firstly, some of the data in Rainis still comes from narratives and other texts where tokenfocusing sentences are less likely to appear than in dialogue-like personal correspondence. The examples of tikt + PPA in Saeima, on the contrary, are found in relatively short speeches by deputies, in other words, they can be compared to somewhat longer lines in real dialogues. ${ }^{9}$ Secondly,

\footnotetext{
${ }^{9}$ The exact length of any 'speech' given by a deputy is seen from looking at a wider context which normally includes both the beginning and the end of the speech, as well as the words of previous and following speakers.
} 
and more importantly, it is likely that the use of the construction by the Saeima deputies differs from its original use, exemplified by Jaunsudrabiņš and Rainis' writings. The number of deputies that use the construction is large enough (more than a hundred) to suggest that they cannot all have inherited it from their dialectal background (to the extent that they have one). This means that they may occasionally adopt the construction from the standard language even if it is not part of their idiolect.

Before turning to particular contexts that seem to elicit the construction from the Saeima deputies, we describe more typical uses resembling the picture that emerges from the other three sources. The first thing to mention is that tikt + PPA is still found in contexts where a perfect (73) or a preterite (74) can be used instead. Pluperfect contexts (75) are more difficult to find.

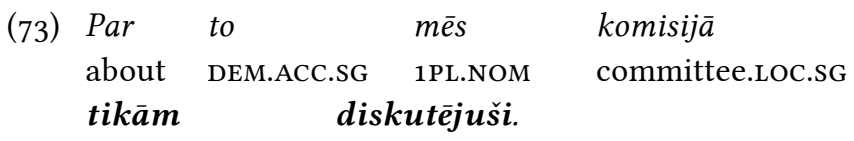

TIKT.PST.1PL discuss.PPA.NOM.PL.M

'We have been discussing this in the committee.'

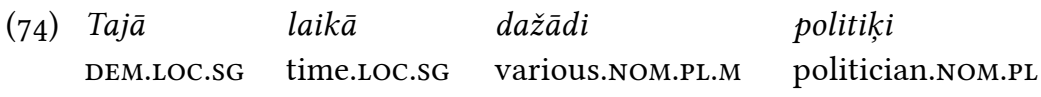

tika solījuši šīs

TIKT.PST.3 promise.PPA.NOM.PL.M DEM.GEN.SG.F

problèmas pozitìvu risinājumu.

problem.GEN.SG positive.ACC.SG solution.ACC.SG

'At that time many politicians promised a positive solution to this problem.'

(75) <... nozarē, kuras pārraudzību no valsts

branch.LOC.SG REL.GEN.SG supervision.ACC.SG from state.GEN.SG

puses "Vatienotība" iepriekš tika

part.GEN.SG self.NOM.SG.F PN.NOM.SG before TIKT.PST.3

destroy.PPA.NOM.sG.F

iznīcinājusi.

'<..> in a branch in which Unity [a political party] itself had previously abolished State supervision.'

Additionally, the construction often conveys events of a certain type recurring over a longer period of time. See also an example with negation in (78): 
(76) [Laikā, kad tika spriests par Satversmes preambulu,]

$\begin{array}{llll}\text { tiku } & \text { saņēmis } & d a u d z & d a \check{a} \bar{a} d u \\ \text { TIKT.PST.1SG } & \text { receive.PPA.NOM.sG.M much } & \text { various.GEN.PL } \\ \text { viedoklu } & \text { un } \quad \text { aicinājumu. } & \\ \text { opinion.GEN.PL } & \text { and invitation.GEN.PL } & \end{array}$

'[During the time when the preamble for the Constitution was discussed] I received a lot of varied opinions and suggestions.'

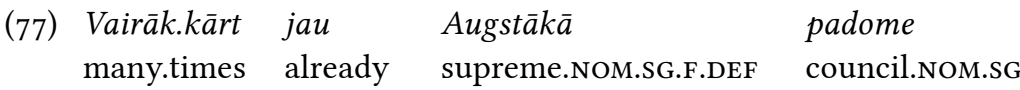

tika izskatījusi jautājumu par

TIKT.PST.3 consider.PPA.NOM.SG.F question.ACC.SG about

to,

DEM.ACC.SG

[kā paātrināt arhīva darbu] <...>

'The Supreme Council (has) repeatedly considered the question [how to speed up the work of the archive] <..>?

(78) [Mēs zinām,

$\begin{array}{lllll}k a & \text { laikmeta } & \text { grieži } & \text { Latvijas } & \text { ļaudis } \\ \text { COMP } & \text { epoch.GEN.SG } & \text { turn.NOM.PL } & \text { Latvia.GEN.SG } & \text { people.ACC.PL } \\ \text { netika } & \text { saudzējuši. } & & \\ \text { NEG.TIKT.PST.3 } & \text { spare.PPA.NOM.PL.M } & \end{array}$

'[We know] that junctures of time have never been easy for the people of Latvia.'

Though tikt + PPA frequently occurs with adverbs meaning 'many times', these are less common than adverbs referring to calendar time, such as in the year/month/on day x', 'x years/months/days ago' and including, for example, 'yesterday'.

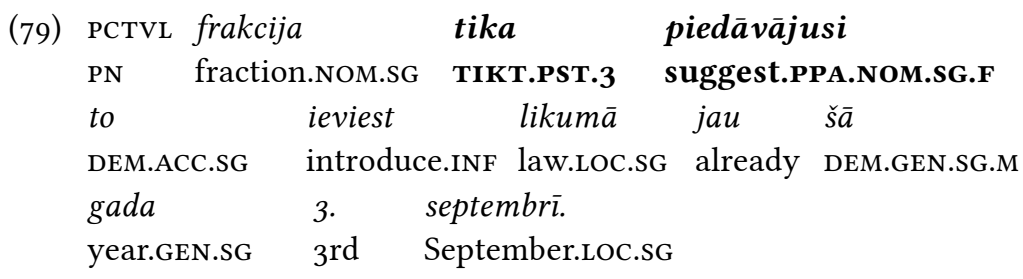

'The PCTVL fraction suggested that this should be made law as early as September 3 of this year.'

The latter feature unites Saeima with Rainis, which is not surprising since Saeima, too, has a very large share of sentences referring to individual events. Although some such sentences are type-focusing, as in (80) below, 
about half of all examples in Saeima can be viewed as token-focusing, which is a lot even in comparison to Rainis.

(80) < ...> [tagad tā tiek anulēta jau tad, ja cilvēks vairāk nekā sešus mēnešus gadā meklē darbu ārpus Latvijas robežām vai]

pirms desmit gadiem tika sniedzis

before ten year.DAT.PL TIKT.PST.3 provide.PPA.NOM.sG.M

par sevi nepatiesas zinas.

about RFL.ACC false.ACC.PL.F information.ACC.PL

' $<\ldots>$ [now it (sc. the permit) is cancelled as soon as a person has been looking for a job outside Latvia for more than six months or] has provided false information about themselves over a period up to ten years.'

Token-focusing interpretation, of course, does not exclude that an event may encompass more than one moment in time, although such examples as in (81) are not common.

(81) Šo

DEM.ACC.SG

sākumā

beginning.LOC.SG

izṇèmuši

out.take.PPA.NOM.PL.M from

kastītēm <...>

box.DIM.DAT.PL

'In the beginning of the year you took this recommendation thrice from your deputies' boxes <...>

The reason why these token-focusing sentences conveying individual events are so frequent in Saeima may be that apart from their uses in an experiential meaning they are also used in place of a resultative (plu)perfect.

(82) Tātad šo

thus DEM.ACC.SG

dokumentu

$m \bar{e} s$

tikām

atzinuši

dokument.ACC.SG

1PL.NOM

TIKT.PST.1PL

acknowledge.PPA.NOM.PL.M PRED

steidzamu.

'We have thus recognised this document as urgent.'

(83) <... [tad mēs faktiski esam nostājušies pret visu Eiropu,]

kurā mēs tikām integrējušies.

REL.LOC.SG 1PL.NOM TIKT.PST.1PL integrate.PPA.NOM.PL.M.RFL

'<..> [therefore we have actually positioned ourselves against all

Europe,] into which we have integrated.' 
The above example (72), here repeated as (84), calls for a resultative interpretation, especially if one remembers that the sentence describes the results of recent elections.

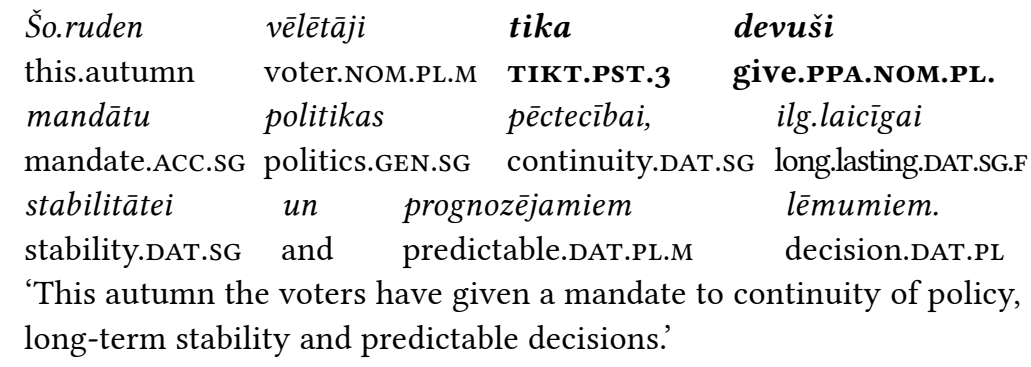

The use of tikt PPA with a resultative meaning in Saeima is associated with certain verbs that serve to describe situations typical of parliamentary procedures: iesniegt 'submit', san,emt 'receive', atbalstīt'support', gūt atbalstu 'receive support'. The examples below evidently deal with having or not having legislative proposals at the reference time (resultative meaning) rather than with carrying out the action of receiving them (experiential meaning), and so on.

(85) [12. pantā nav citu priekšlikumu. Bija tikai tie,]

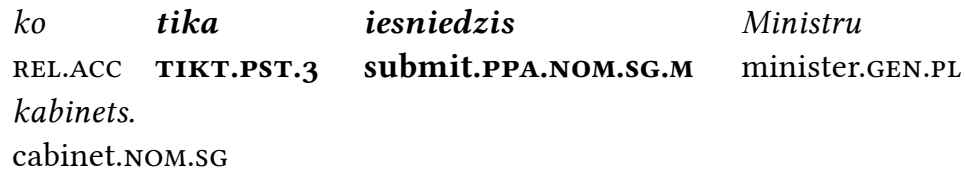

(86) [Mēs atstājam šo normu spēkā-vēl jo vairāk tādēl,,]

$\begin{array}{llll}\text { ka citu } & \text { normu } & \text { rakstveidā ne.viens } \\ \text { COMPL } & \text { other.ACC.SG } & \text { norm.ACC.SG } & \text { in.writing no.body.NOM.SG } \\ \text { mums } & \text { ne.tika } & \text { iesniedzis. } \\ \text { 1PL.DAT } & \text { NEG.TIKT.PST.3 } & \text { submit.PPA.NOM.SG.M }\end{array}$

'[We upheld this norm - the more so because] nobody had submitted any alternative norms to us in writing.'

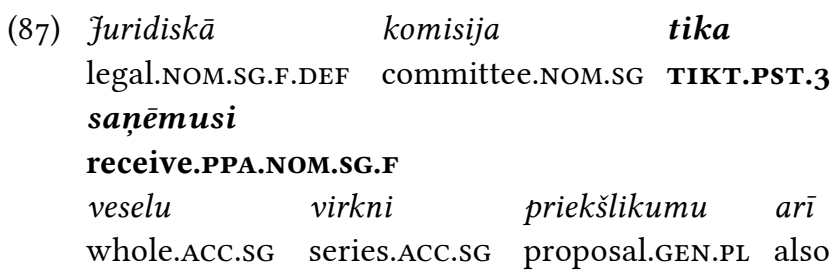


trešajam lasījumam $<\ldots>$

third.DAT.SG.M.DEF reading.DAT.SG

'The Legal Committee has received a whole series of proposals for the third reading as well <...>

Rather than being a unique property of Saeima, resultative meaning can be also found in other modern texts, notably in miljons-2.o, where the most obvious example of a resultative $t i k t+$ PPA remains (72). Some examples in earlier texts by Jaunsudrabiņš (88) and Rainis (89) are ambiguous between an experiential and a resultative interpretation and may have therefore served as a basis for the later development.

(88) [Es neticu, vai kāds cilvēka bērns pasaulē uzaudzis bez kašķa.]

$\begin{array}{lllll}\text { Es } & \text { ar } & \text { viņu } & \text { tiku } & \text { aplipis } \\ \text { 1SG.NOM with } & \text { 3.ACC.SG } & \text { TIKT.PST.1SG } & \text { be.covered.PPA.NOM.SG.M } \\ \text { vairākiem } & \text { lāgiem. } & \\ \text { many.DAT.PL.M } & \text { time.DAT.PL } & \end{array}$

'I don't believe that any human child could have grown up without scabies. I have been covered with it many times.'

(89) < ...> [satversmi jeb konstitūciju pieprasīja tanī pat 1905. gada sākumā latviešu inteliğence savā petīcijā,]

kuru es tiku izstrādājis

REL.ACC.SG 1SG.NOM TIKT.PST.1SG draw.up.PPA.NOM.SG.M

[un kura ievietota nākoša nodaḷā.]

'<...> [a Satversme, or constitution, was demanded in the same early months of 1905 by the Latvian intelligentsia in their petition,] which I had drawn up [and which can be found in the next chapter.]'

In the course of this development, $t i k t+$ PPA is identified with a regular (plu)perfect. Several examples in Saeima suggest the construction can also be used to convey the meaning of 'current relevance'; usually with the adverbs nupat and tikko both meaning 'a moment ago':

(90) Nupat tika izskanējusi doma <...> just.now TIKT.PST.3 be.voiced.PPA.NOM.sG.F idea.NOM.sG

'The idea has just been voiced [that] <...'

(91) <... [jo tas ir saistīts ar debatēm,]

kas tika izskanējušas

REL.NOM TIKT.PST.3 be.voiced.PPA.NOM.PL.F

pirms brïža $<\ldots>$

before moment.GEN.SG

' $<\ldots>$ [because this concerns the dispute] that took place a moment ago $<\ldots$ '. 
All these facts suggest that $t i k t+$ PPA has extended to a number of functions belonging to the domain of the resultative perfect, from which it had been barred in the dialects where it was indigenous. As mentioned above, the identification of $t i k t+$ PPA with a regular perfect is also reflected in Grigorjevs, ed. (2013,479-480). But due to the fact that in our construction the auxiliary has only the past-tense form, it can be identified with both the perfect and the pluperfect. At the same time, the construction is still broadly used in contexts where it can be replaced with a preterite (with which it is identified in Bergmane et al., eds., 1959, 594). Still, it differs from the preterite in that it basically occurs in non-narrative contexts.

It is striking that in spite of the apparent widening of the functional scope of constructions with tikt its relative frequency has not increased: $t i k t+$ PPA remains a marginal construction in the modern language, its frequency being noticeably lower in comparison with the earlier texts by Rainis and Jaunsudrabiňs. We could speculate that with the extension of its scope our construction has become more of a stylistic or genre-connected variant of the three tense forms referring to past events - preterite, perfect and pluperfect, without noticeable restrictions of the kind we observe in older writers.

An interesting difference emerging from a comparison of Rainis and the Saeima corpus is that the ratio of 1st-person and 3rd-person forms in Saeima is almost the reverse of what we find in Rainis. While Rainis has 124 1SG forms out of a total of 161, as against 15 3rd-person forms, Saeima has 347 3rd-person forms out of a total of 443 , as against 46 for the 1SG. We are not sure how to interpret this difference. Obviously ego-documents constitute a considerable part of the Rainis corpus whereas they are absent from the Saeima corpus, but it is not clear whether the differences can be put down to genre.

\section{Some generalisations}

At the start, we attempted to characterise the preterite with tikt by linking it to experientials, a gram type singled out by Dahl (1985). Many uses of our construction correspond to the notion of experiential as described by Dahl: they often refer to event types and express no precise location in time, specifying instead that one or more instances of this event type have 
or have not taken place within a certain time frame closed (at least) at the end, either by the moment of speech or by some reference time in the past.

The features enumerated here are those singled out by Dahl. Within the notion of experiential emerging from the above characterisation, we can make our description more precise by saying that

- the time-frame within which the event type is said to have been or not to have been instantiated can either be closed by speech time, in which case it could be replaced with an experiential perfect, or it can be closed by a reference time in the past, in which case it could be replaced with an experiential pluperfect.

- the time-frame can be closed at both ends, as in during the whole journey I didn't laugh a single time, and in this case our construction could only be replaced with a simple past tense, not with a perfect or pluperfect.

But the use of our construction is actually wider in the sense that it can refer not only to event types but also to individualised events, precisely anchored in discourse space. So, for instance, it can refer to the posting of letters in general but also to the posting of a particular letter promised to or expected by another discourse referent. The anchoring of an event in discourse space is not equivalent to the statement of its having taken place; this may be either affirmed or negated. In this way we arrive at, what in Russian aspectology, has been called the 'factual meaning', manifesting itself, for example, in questions like

(92) Russian

[A esli prizyvnik uničtožit pis'mo, kak potom voenkomatu dokazat',] čto on voobšče posylal?

COMPL 3.SG.NOM.M 3.SG.ACC.N at.all send[IPFV].PST.sG.M

'[And if a draftee destroys the letter, how is the military commissariat supposed to prove] that it sent it at all?' ${ }^{\prime 10}$

We have thus actualisation of an event instead of instantiation of an event type. Is this still an experiential? In what way does it differ from, say, a simple past?

\footnotetext{
${ }^{10}$ https://aif.ru/dontknows/actual/poyavyatsya_elektronnye_povestka_i_bolnichnyy
} 
The crucial question is whether the characteristic element of temporal indefiniteness still holds. As long as we are talking about event types, time frames tend to be longer as we are thinking about event types possibly recurring within a scale of weeks, months or years. When talking about anchored events, we scale down to shorter periods in which this event was expected or may be assumed to have occurred. When we arrive at adverbials like 'yesterday' or 'this morning', we may legitimately ask whether the time indefiniteness proper to experientials still applies.

An important point is, however, that the verb form is not narrative. Narrative texts create a shifting time frame whose correspondence to the immobile time frame measured in years, months and calendar days is not always specified but does not need to be specified because the narrative creates its own time frame. The defining feature of forms with tikt seems to be that they do not depend on a narrative time frame. To be sure, they do not exclude it, e.g. in example (37) above (During the whole journey I didn't laugh a single time) the journey is part of a narrative time frame. But the time frame can be an absolute one, not dependent on a narrative, e.g., 'yesterday'. Within this time frame, the occurrence or non-occurrence of a situationally anchored event is asserted.

We have attempted to characterise the use of $t i k t+$ PPA across genres, the main line of division being narrative vs non-narrative, and across periods, contrasting older writers who presumably had a native competence in the original use of our construction with the usage in speakers of the contemporary standard language. Our initial hypothesis was that the adoption of the tikt + PPA construction, originally a feature of High Latvian dialects, as a feature of the standard language, sanctioned by its use in renowned writers, must have led to changes in the principles governing its use. This was confirmed. Where it was indigenous, the $t i k t+$ PPA construction was originally an experiential tense in a broader sense, comprising not only reference to event types without precise location on the axis of time, but also statements of the occurrence or non-occurrence of a situationally anchored event within a relatively restricted time frame. This original use could be characterised as nonresultative and non-narrative. In modern usage the tikt + PPA construction is still non-narrative, but seems to have widened its scope by extending to resultative contexts. 


\section{AbBreviations}

ACC - accusative, ACN - action noun, ADJ - adjective, ADV - adverb, AOR - aorist, COMP - comparative, COMPL - complementiser, CVB - converb, DAT - dative, DEF - definite, DEM - demonstrative, DIM - diminutive, EVID - evidential, F - feminine, FUT - future, GEN - genitive, INDEF indefinite, INF - infinitive, INT - interrogative, IPFV - imperfective, IRR - irrealis, LOC - locative, $\mathrm{M}$ - masculine, $\mathrm{N}$ - neuter, NEG - negation, NOM - nominative, PL - plural, PN - personal name, PPA - past active participle, PPFA - perfect active participle, PPP - past passive participle, PRED - predication marker, PRS - present, PST - past, PTC - particle, PTCP - participle, RFL - reflexive, REL - relative pronoun, RPOSS - reflexive possessive, SG - singular

\section{REFERENCES}

Ancītis, KrišjĀAnis. 1935. Par Ancītes izloksni. Fakti un piezīmes.

[On the dialect of Ancīte. Facts and observations.]

Filologu Biedrïbas raksti 15, 161-196.

AnCĪtis, KrišJĀNIS. 1977. Aknistes izloksne. Izloksnes statika un dinamika.

[The Dialect of Aknīste. The Statics and Dynamics of a Dialect.]

Rīga: Zinātne.

Balode, Laimute \& Axel Holvoet. 2001. The Latvian language and its dialects. In: Östen Dahl \& Maria Koptjevskaja-Tamm, eds., The CircumBaltic Languages. Vol. I: Past and Present. Amsterdam-Philadelphia: John Benjamins, 3-40.

Bergmane, Anna et al., eds. 1959. Mūsdienu latviešu literārās valodas gramatika I. Fonētika un morfologiija [Grammar of Modern Literary Latvian. Phonetics and Phonology]. Riga: Latvijas PSR Zinātņu akadēmija.

Dahl, Östen. 1985. Tense and Aspect Systems. Oxford: Blackwell.

DAhl, Östen \& Eva Hedin. 2000. Current relevance and event relevance. In: Östen Dahl, ed., Tense and Aspect in the Languages of Europe. Berlin etc.: Mouton de Gruyter, 385-401.

Dahl, Ósten \& Viveka Velupillai. 2013. The Perfect. In: Matthew S. Dryer \& Martin Haspelmath, eds., The World Atlas of Language Structures Online. Leipzig: Max Planck Institute for Evolutionary Anthropology. (Available online at http://wals.info/chapter/68, accessed on 2018-12-08.)

Daugavet, AnnA. 2015. Razvitie leksičeskix i grammatičeskix značenij latyšskogo glagola tikt [The development of lexical and grammatical 
meanings of the Latvian verb tikt]. Vestnik Sankt-Peterburgskogo gosudarstvennogo universiteta. Serija 9: Filologija. Vostokovedenie. Žurnalistika. 3, 49-59.

Daugavet, AnnA. 2015. Latvian dabūt 'get'. An acquisitive modal? Baltic Linguistics 6, 9-44.

Endzelin, JAN. 1923. Lettische Grammatik. Heidelberg: Carl Winter.

GrigorJevs, JURIs, ed. 2013. Latviešu valodas gramatika [Latvian Grammar]. Rìga: LU Latviešu valodas institūts.

Grønn, Atre. 2003. The Semantics and Pragmatics of the Russian Factual Imperfective (Acta Humaniora). Faculty of Arts, University of Oslo.

Hauzenberga, Edīte. 1934. Liezēriešu izloksne [The dialect of Liezēre]. Filologu Biedrības Raksti 14, 172-197.

Holvoet, Axel. 2001. Studies in the Latvian Verb. Kraków: Wydawnictwo Uniwersytetu Jagiellońskiego.

IndĀne, Irma. 1986. Dignājas izloksne [The Dialect of Dignāja]. Rīga: Zinātne.

KartTunen, LAURI. 1971. Implicative verbs. Language 47.2, 340-358.

KipArsky, PAUl. 2002. Event structure and the perfect. In: David I. Beaver, Luis D. Casillas Martínez, Brady Z. Clark \& Stefan Kaufmann, eds., The Construction of Meaning. CsLi Publications, 113-132.

LAgZdin̦A, SARmīte. 1998. Adverbien, Präpositionen oder Halbpräpositionen? Linguistica Baltica 7, 151-166.

Mehlig, Hans Robert. 2013. Obščefaktičeskoe i edinično-faktičeskoe značenie nesoveršennogo vida v russkom jazyke [The general-factual and singular-factual meanings of the imperfective aspect in Russian]. Vestnik Moskovskogo universiteta, serija 9: Filologija. 2013.4, 19-47.

MüHlenbach, KarL. 1905/2011. Das Suffix -uma-im Lettischen. Eine Skizze aus dem Sprachleben. Indogermanische Forschungen 27, 402-436. Reprinted in: Darbu izlase 2, ed. Ina Druviete, Rīga: Lu Latviešu valodas institūts, 219-239.

NAU, Nicole. 2011. A Short Grammar of Latgalian (Languages of the World / Materials, 482). München: Lincom Europa.

Nau, Nicole \& Axel Holvoet. 2015. Voice in Baltic: An overview. In: Axel Holvoet \& Nicole Nau, eds., Voice and Argument Structure in Baltic. Amsterdam-Philadelphia: John Benjamins, 1-36.

PoišA, MaIja. 1985. Vidzemes sēliskās izloksnes [The Selonian Dialects of Vidzeme]. Rīga, Zinātne. 
Reichenbach, Hans. 1947. The tenses of verbs. In: Elements of Symbolic Logic. New York: Macmillan, 287-98.

Rix, Helmut et al. 2001. Lexikon der indogermanischen Verben. Die Wurzeln und ihre Primärstammbildungen. 2nd ed. Wiesbaden: Ludwig Reichert.

RūḳE, Velta \& KĀRlis Draviñš. 1958. Verbalformen und undeklinierbare Redeteile der Mundart von Stenden. 2. Verben, Adverbien, Präpositionen und Präfixe, Partikeln, Konjunktionen. Lund: Slaviska Institutionen.

Smoczyński, Wojciech. 2018. Lithuanian Etymological Dictionary. Berlin etc.: Peter Lang.

Vīksne, Irma. 1937. Daudzesiešu izloksne [The dialect of Daudzese]. Filologu Biedrības Raksti 17, 143-161.

Vīksne, Irma. 1940. Sēlpiliešu izloksne [The dialect of Sēlpils].

Filologu Biedrības Raksti 20, 59-74.

\section{Anna Daugavet}

Vilnius University \& St Petersburg University

Department of General Linguistics

Universitetskaya nab. 11

RU-199034, St Petersburg

a.daugavet@spbu.ru

\section{Axel Holvoet}

Vilnius University

Institute for the Languages and Cultures of the Baltic

Universiteto 5

LT-01131 Vilnius

axel.holvoet@flf.vu.lt 